\section{Luba Dovgan Nurse Valentina Ljubić Tobisch}

Luba Dovgan Nurse lubadnurse@gmail.com

Valentina Ljubić Tobisch valentina.ljubic.tobisch@gmail.com

Pregledni članak / Scientific review

Primljen / Received: 2. 7. 2021.

UDK: 7.025.4:[685.51-035.51 (497.5 Dubrovnik)"15"

739.1 Kuster, Peter DOI: https://doi.org/10.17018/portal.2021.3

\title{
Two leather-covered cases
}

\section{attributed to the Nuremberg goldsmith Peter Kuster, c. 1550}

ABSTRACT: Close-fitting cases (German term Futterale) for silverware of the Renaissance period have received much less attention than the artefacts they were designed to protect. These cases are significant in that, together with the silverware, they make an ensemble and provide insight into the historical practices of care and display of treasures. The ewer-and-basin set, dating to c. 1550 and attributed to the Nuremberg goldsmith Peter Kuster, from the Reliquary of the Cathedral of the Assumption of the Virgin Mary in Dubrovnik, Croatia, underwent technological and scientific investigation, and conservation treatment for an exhibition in 2019. The paper offers an overview of the definition of fitting cases, Futterale, the materials, and the techniques of making such cases, provides historic examples of cases for comparison, and discusses the issues surrounding their preservation. The construction details and condition of the cases by Peter Kuster are provided, followed by a summary of the conservation treatment carried out. The paper contributes to the understanding of Renaissance materials and techniques and the historical practices of care for valuable artefacts.

KEYwoRDs: Renaissance leather cases, Nuremberg, Peter Kuster, Cathedral Treasury Dubrovnik, embossed leather, goldsmith, conservation treatment

I $\mathrm{n}$ the $16^{\text {th }}$ century the imperial city of Nuremberg became one of the most important centres of goldsmithing and the production of luxury goods of the Holy Roman Empire. A great influence on the development of the arts came with the adoption of Lutheranism (1525), which brought changes to the traditional forms of religious goldsmithing arts, such as liturgical objects, reliquaries and crosses. The main change for the arts was the new source of patronage, with the church being no longer the main patron, the urban aristocracy commissioning secular items, and artists in response developing new secular styles. ${ }^{1}$ In residential settings the display of artefacts became more important, reflecting the idea cultivated during the Renaissance period of collecting and showing unique, rare and extraordinary things, made by nature and man. This desire to collect and display artefacts led to the development of new types of furniture in the form of cupboards and elaborate cabinets. Close-fitting cases could be made attractive for display, while remaining functional, and became a very important element of care for unique items, in addition to the earlier types of storage furniture, such as chests and boxes. Cases were made to fit specific objects and were commissioned at the same time as the objects. ${ }^{2}$ Historic sets comprising silverware and its original case make up an ensemble, that is a meaningful unit of items to be assessed, interpreted and preserved as a whole. This approach recognises the "whole" as more valuable than the sum of its parts. ${ }^{3}$ 


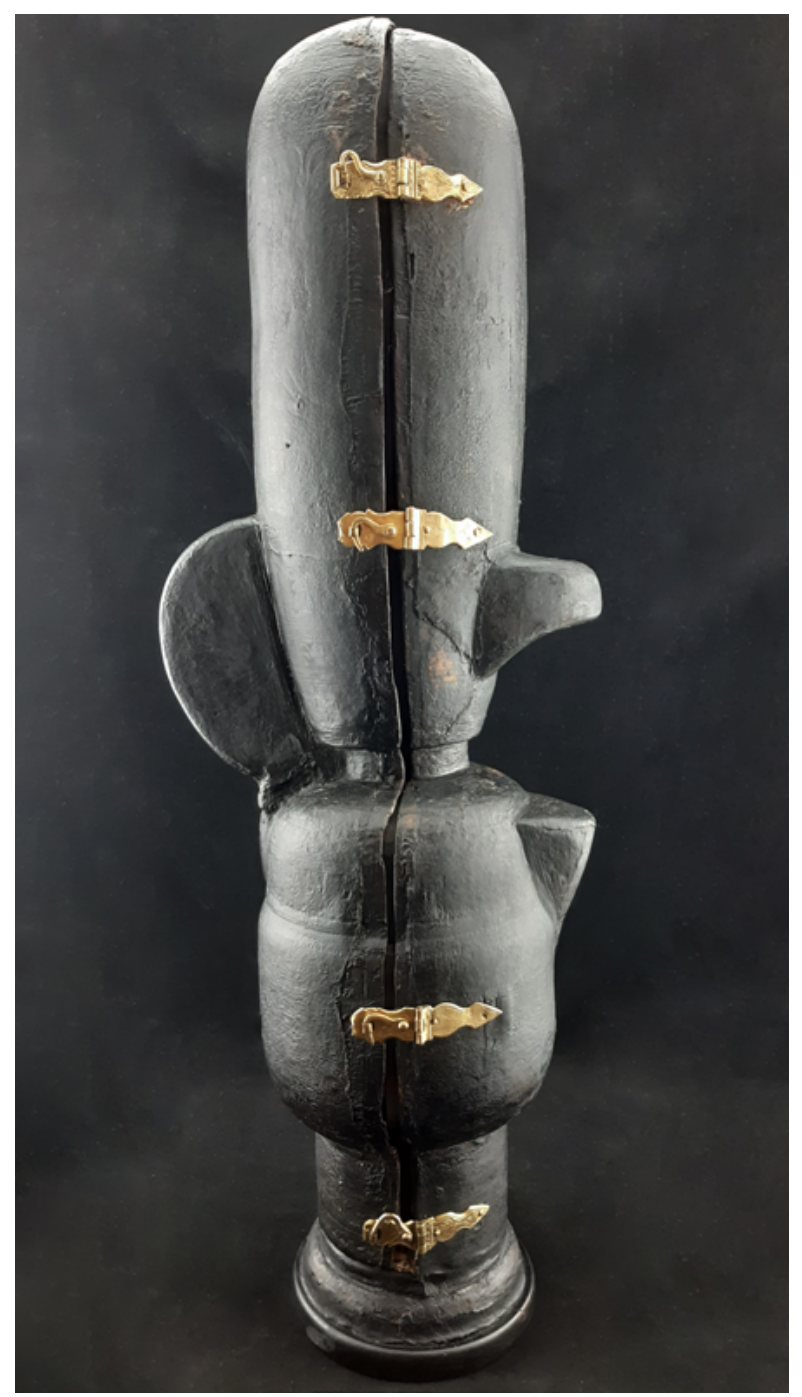

1a. Case, associated with ewer made by Peter Kuster, Nuremberg, Treasury of the Dubrovnik Cathedral, Croatia. Condition before conservation (V. Ljubić Tobisch, 2019)

Futrola povezana s vrčem Petera Kustera, stanje prije radova, Riznica dubrovačke katedrale (snimka: V. Ljubić Tobisch, 2019.)

Two examples of such cases from the Renaissance period have been preserved in Dubrovnik, Croatia, as parts of a magnificent lavabo set consisting of a ewer and basin, attributed to the Nuremberg goldsmith Peter Kuster, dating to c. $1550^{4}$ (Figs 1, 2 and 3). In 2019 the metal artefacts and the original leather-covered cases from the Reliquary of the Cathedral of the Assumption of the Virgin Mary in Dubrovnik, Croatia, were prepared to go on loan to the exhibition „Making Marvels: Science \& Splendor at the Courts of Europe" at the Metropolitan Museum of Art in New York. ${ }^{5}$ The project provided an opportunity for the authors to examine the cases, and to carry out a minimal conservation treatment to improve their condition and reinstate their appearance. To gain a better understanding of the artefacts and their historical context, we reviewed the published sources concerning Futterale to find the literature limited, perhaps reflecting

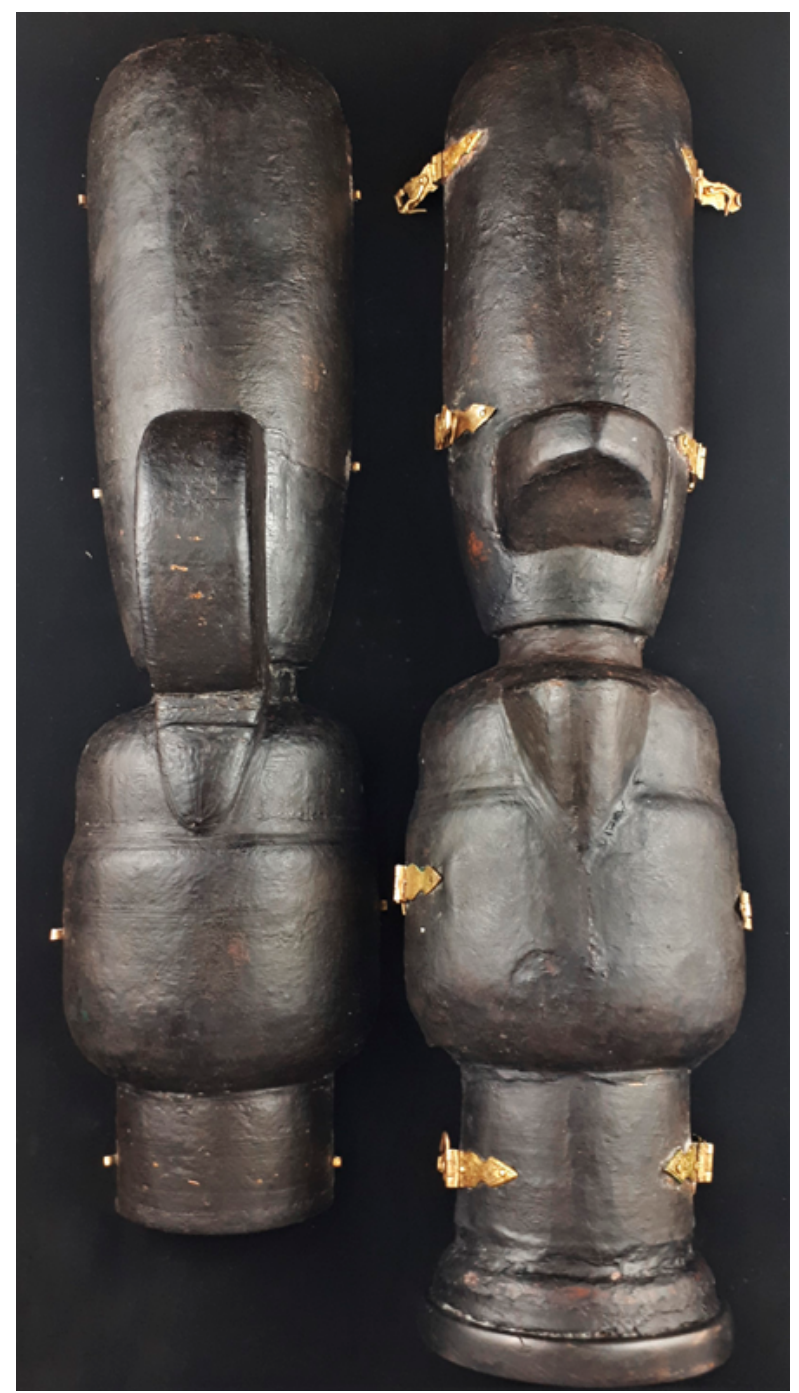

1b. Case, associated with ewer made by Peter Kuster, Nuremberg, Treasury of the Dubrovnik Cathedral, Croatia. Leather cover before conservation (V. Ljubić Tobisch, 2019)

Futrola povezana s vrčem Petera Kustera, kožni poklopac prije radova (snimka: V. Ljubić Tobisch, 2019.)

the marginal importance of the cases in comparison to the silverwork. Cases associated with specific artefacts appear in collection catalogues; each has to be looked at in its specific historic context. ${ }^{6}$ There is also little documentation on cases in the conservation literature, and for the Kuster set in particular there is a lack of provenance information and preservation history. Although limited, the review of published sources improved our understanding of the historic contexts, materials and techniques of the Renaissance art in Nuremberg, and informed our assessment of the condition of the silverware and the cases, of their decay and the damage to the materials.

The spectacular ewer-and-basin set is the only known surviving artefact carrying Peter Kuster"s mark. The Nuremberg hallmark „N“ and Peter Kuster“s mark „VAT“" (Fig. 4) are stamped into the spout of the ewer. It is unknown whether Kuster had sufficient financial means 


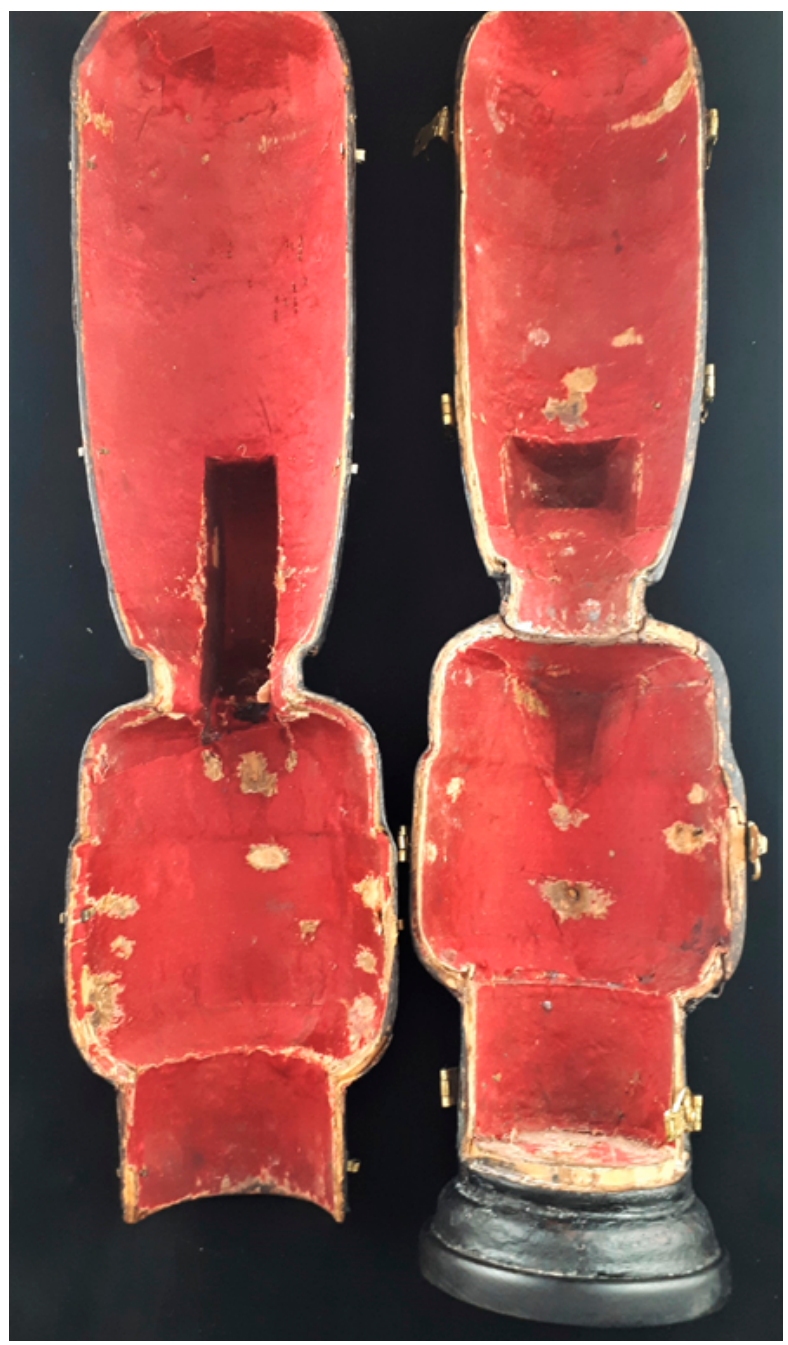

1c. Case, associated with ewer made by Peter Kuster, Nuremberg, Treasury of the Dubrovnik Cathedral, Croatia. Silk lining before conservation (V. Ljubić Tobisch, 2019)

Futrola povezana s vrčem Petera Kustera, podstava od svile prije radova (snimka: V. Ljubić Tobisch, 2019.)

to carry out this great work alone or it was a commission from a wealthy patron. The ewer and basin are made of silver and mostly fire-gilded. A special characteristic is given to this goldsmithing work by more than 80 life casts of animals such as lizards, frogs, crabs, fish, snakes, tadpoles and snails, and various plants, made after natural models and painted in their natural colours. The lavabo set is characteristic of the late Renaissance and Mannerist predilection for naturalistic forms in imperishable and eternal materials; ${ }^{8}$ the painted life casts of small animals and plants deprive the ewer-and-basin set of its utilitarian function, making it a pure showpiece.

The fact that the life and work of Peter Kuster are connected with Florence allows the possibility that this lavabo set came to Dubrovnik from Italy. ${ }^{9}$

Peter Kuster joined the goldsmiths" guild of Nuremberg in 1544 (documented 1544-1559). ${ }^{10}$ Kuster's neighbour was Wenzel Jamnitzer, who already by this time was one of Nuremberg's most renowned goldsmiths. Although the two goldsmiths shared a fascination for the production of life casts, Kuster's lavabo set differs stylistically from the symmetry recognisable in Jamnitzer's works. Life casts of plants and animals were especially popular and valued in the 16th century. However, only a small number of goldsmiths worked in the technique of life casting, due to the considerable effort and time required for collecting models, making the moulds, preparing the animals and plants, casting them in metal, and painting them to imitate their natural appearance ${ }^{11}$. Both goldsmiths - Jamnitzer and Kuster - used a press for metal, horn and wood ${ }^{12}$ built especially for them by the Nuremberg craftsman Hans Lobsinger. ${ }^{13}$

Because of the use of the same techniques and tools, the neighbourly relationship, and a suggested rivalry, ${ }^{14}$ it is not surprising that the works of these two goldsmiths show certain similarities and are often compared. ${ }^{15}$ The similarity between the work of these masters does not stop at the silverwork and extends to the leather cases, and can be seen when comparing the case made by Jamnitzer's workshop for the Merkelscher Aufsatz (Merkel's Table Piece) (Fig. 5a), with the case for the ewer by Kuster (Fig. 1 a - c). In-depth comparison of these cases is required to address the questions of competition between these two masters.

\section{A close-fitting case: an introduction to historic materials, techniques and use}

The most suitable term that describes a close-fitting case of such type is Futteral in German and futrola in Croatian. Friedrich Kobler gives the following definition: „Futteral is... a lockable, shell type (case) for the protection of an object, fitting closely its shape“. ${ }^{16}$ The French term étui is often used synonymously with Futteral; however, étui is more correctly applicable to small, flat cases that do not follow the object's shape and, in particular, to those cases that have an opening for inserting objects. The Futteral (futrola) type of case is always custom-made for a unique item, the shape of the object determining the form of the case; and, since it was custom made, the case could seldom be used for another object. Fitting cases were made for musical instruments, hunting weapons, pistols, sword scabbards, valuable travel utensils, optical and technical instruments, jewellery and liturgical objects. The practice survives today with cases being made for liturgical chalices and patens, as well as for musical instruments and luxury goods. Then and now the cases accompany luxurious items, projecting the message of carrying for something precious, valuable and unique.

Close-fitting cases were relatively light in weight, and easy to carry and transport. The smaller ones, designed for personal items - for example, for eating and drinking utensils - were preferably worn on the belt; cases for 


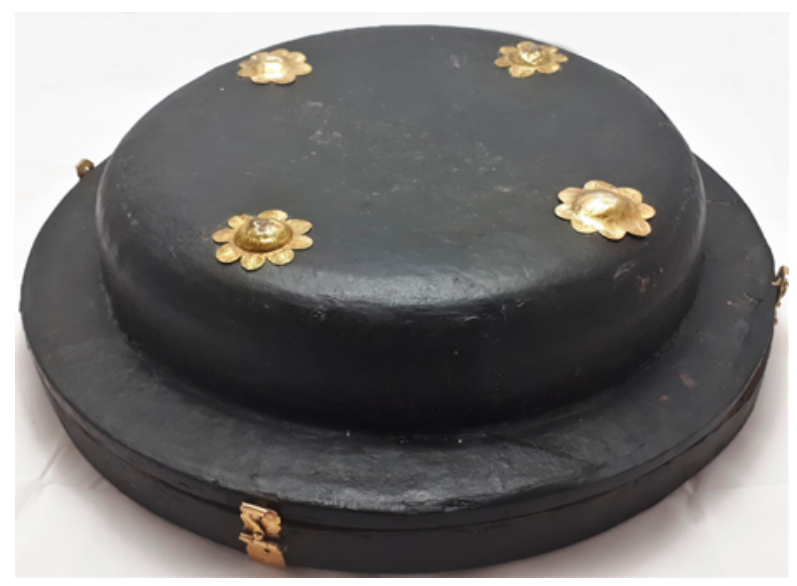

2. Case associated with basin made by Peter Kuster, Nuremberg, Treasury of the Dubrovnik Cathedral, Croatia. Condition before conservation (V. Ljubić Tobisch, 2019)

Futrola povezana s umivaonikom Petera Kustera, stanje prije radova, Riznica dubrovačke katedrale (snimka: V. Ljubić Tobisch, 2019.)

hunting were attached to a saddle, while the larger and most valuable items were transported by carriages. ${ }^{17}$

There were three main ways of making close-fitting cases: entirely from wood; from moulded leather (socalled cuir bouilli) ${ }^{18}$ that became rigid after treatment and kept its shape; and from composite materials with wood or paper as foundation, covered in leather, parchment, fish skin or paper, often embossed with gold, lined in leather, silk or velvet, and finished with metal clasps. The term cuir bouilli (a medieval French term translated as „boiled leather"), which is often used for moulded leather, serves as a general title and not as a description of the process ${ }^{19}$. Mistakenly, the term cuir bouilli is often applied to other leather decoration techniques.

The most commonly used leather for case-making came from vegetable-tanned calfskin, cowhide, sheepskin

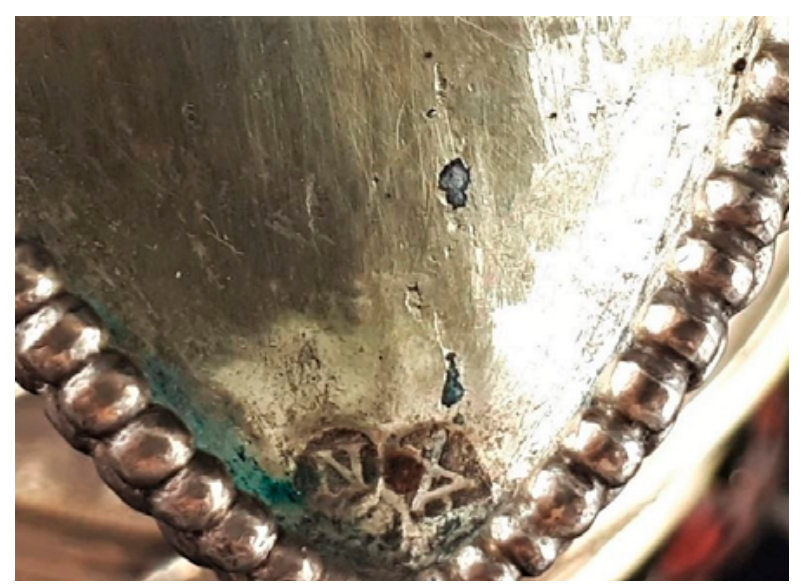

4. City and master hallmark by Peter Kuster, Nuremberg, c. 1550 (V. Ljubić Tobisch, 2019)

Gradska i majstorska punca Petera Kustera, Nürnberg, oko 1550. (snimka: V. Ljubić Tobisch, 2019.)

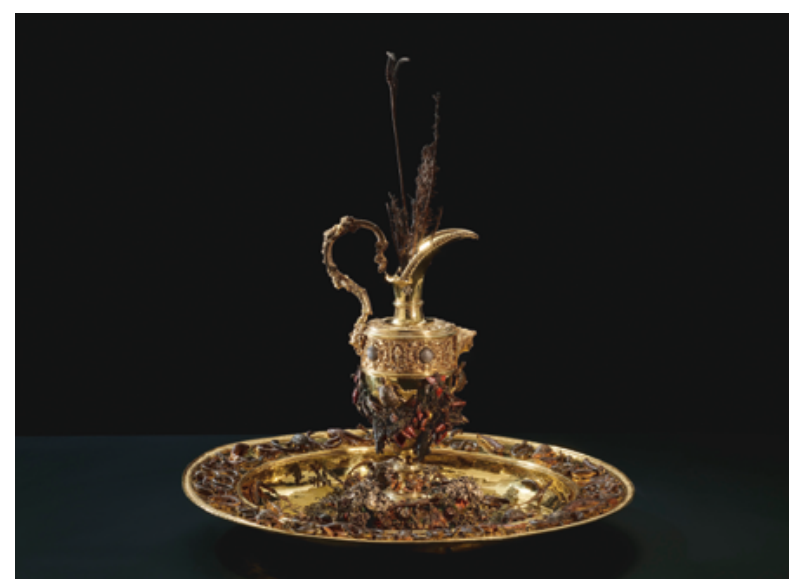

3. Ewer and basin, Peter Kuster, Nuremberg, c. 1550, Treasury of the Dubrovnik Cathedral, Croatia. Ewer: $488 \times 170 \mathrm{~mm}, 2160 \mathrm{~g}$. Basin: $\varnothing 497 \times 80$ mm, 3770 g (R. Staudinger, 2019) Vrč i umivaonik, Peter Kuster, Nürnberg, oko 1550., Riznica dubrovačke katedrale, vrč: 488 x 170 mm, 2160 g. Umivaonik: $\varnothing$ $497 \times 80$ mm, 3770 g. (snimka: R. Staudinger, 2019.)

and goatskin. In making larger cases, and those more complex in form, the leather has a secondary structural function in addition to the wood. Leather, a flexible and thermoplastic material, serves as an overcoat that secures the structure and prevents it from breaking. In the making of leather covers, the leather was often treated with hot water and, before it began to shrink, pulled over a pre-made mould or foundation, and slowly dried. Alternatively, the leather was moistened with cold water and then either stretched over a hot mould or slowly heated in an oven to set the shape. The material properties of leather allow a great choice of decorative techniques, such as cutting (carving), punching, embossing and gilding.

The case conceals the artefact, and the act of opening the case creates an effect of surprise. One of the most magnificent examples of such work is a leather-covered case with beautifully crafted metal clasps, made specifically for the large centrepiece by Jamnitzer, known as the Merkelscher Aufsatz - Merkel's Table Piece (Fig. 5a) - c. 1549, in the collection of the Rijksmuseum in Amsterdam. ${ }^{20}$ Jamnitzer's silver-gilt centrepiece is shaped like a high-footed bowl, surmounted by a vase, the leather-covered Futterale following the bowl's shape. The label reads „The table ornament was kept in a dedicated area of the treasury of the town hall of Nuremberg. The case was opened only on rare occasions for particularly high-ranking guests." Although proportional and well-balanced in construction and size, the case's exaggerated shape, distortion of elements, and elaborate ornamentation reflect the Mannerist fashion of the time. ${ }^{21}$ The decorations, applied as blind or gold embossing, enhanced the luxurious impression, as did the filigree-worked hinges and clasps.

Judging from the images, the wooden core of this case appears to be similar in construction to the ewer case 


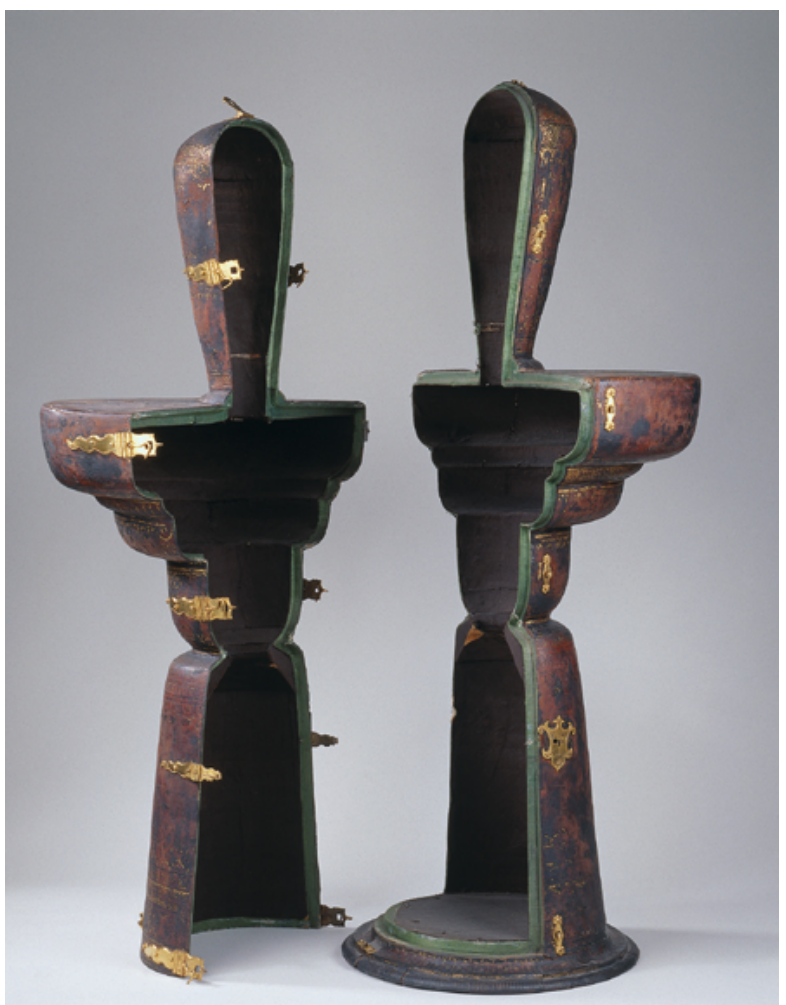

5a. Case for the centrepiece of Wenzel Jamnitzer, 1549, $1095 \times 530$ mm, BK-17040-B, Rijksmuseum Amsterdam.

Futrola za središnji stolni ukras dio Wenzela Jamnitzera, 1549., $1095 \times 530$ mm (Rijksmuseum Amsterdam BK-17040-B,)

from Dubrovnik, consisting of several turned wooden parts, covered in leather, and embellished with stamped gold. The leather has been described by Bennekom as "gold-embossed morocco leather', which suggests it was made from goatskin. ${ }^{22}$ The total price paid for the case was 80 guilders; the order mentions a separate leather bag, which can be interpreted as an additional protection in storage and travels. ${ }^{23}$

The case for the Coconut Goblet of the Holzschuher family, dated c. 1535, from the Germanisches Nationalmuseum in Nuremberg (Fig. 5b) provides another good example of the Mannerist style. The wooden core of this case is covered in leather and decorated in blind and gold embossing with abundant ornaments. The clasps are made from engraved brass, and the interior lining is leather. Immediately noticeable are the similarities in the mould construction with Jamnitzer's and Kuster's cases, even though they came from different goldsmiths' workshops. In comparison with these two decorative cases, the cases from Kuster's set are much simpler and more humble in the choice of materials and decorations, possibly suggesting their utilitarian function as transport and storage.

The collaborative nature of crafts and cooperation between goldsmiths and other craftsmen is evident from the archives, showing that pattern makers and wood

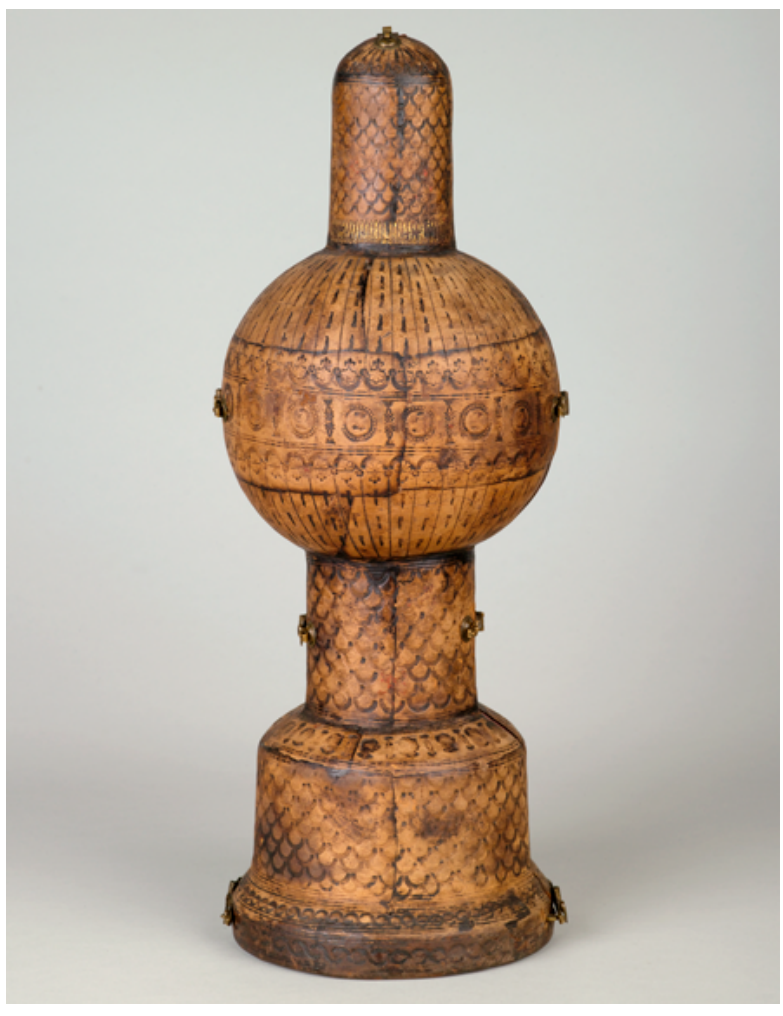

5b. Case for the Coconut Goblet of the Holzschuher family, c.1540, HG11709_2, Germanisches Nationalmuseum (Georg Janßen, n.d.) Futrola za Coconut goblet obitelji Holzschuher, oko 1540., HG11709_2, Germanisches Nationalmuseum (Georg Janßen, n.d.)

sculptors were the main collaborators for the silverwork. ${ }^{24}$ Case making was also a collaborative undertaking, drawing on the knowledge and skills of bookbinders. ${ }^{25}$ Two leather bookbindings from the $16^{\text {th }}$ century in the collection of the National and University Library in Zagreb serve as an example (Figs 6a and 6b). Kobler speaks about the existence of Futterale makers as a separate trade in Nuremberg in the $16^{\text {th }}$ century, and a strict city regulation demanding they learn bookbinding. In 1631, the city of Nuremberg regulated the production of cases, whereby they could be made by two trades: bookbinders, who were allowed to make cases, and a separate trade of case makers, who were prohibited from doing any other work. ${ }^{26}$ Unlike for the goldsmiths' work, there were no guild regulations concerning the application of the master's stamp to Futterale, making the identification of the workshop difficult. Linking the cases to regional styles or particular workshops is possible through the coats of arms and inscriptions, or by comparison.

A treatise by the bookbinder and case maker Christoph Ernst Prediger, published in 1764, Für die Buchbinder und Futteralmacher („For bookbinders and case makers“) is a valuable source of information about the construction, material properties and inherent weaknesses of closefitting cases. ${ }^{27}$ The process began with the making of a wooden core by a turner using dry wood. Prediger warns 


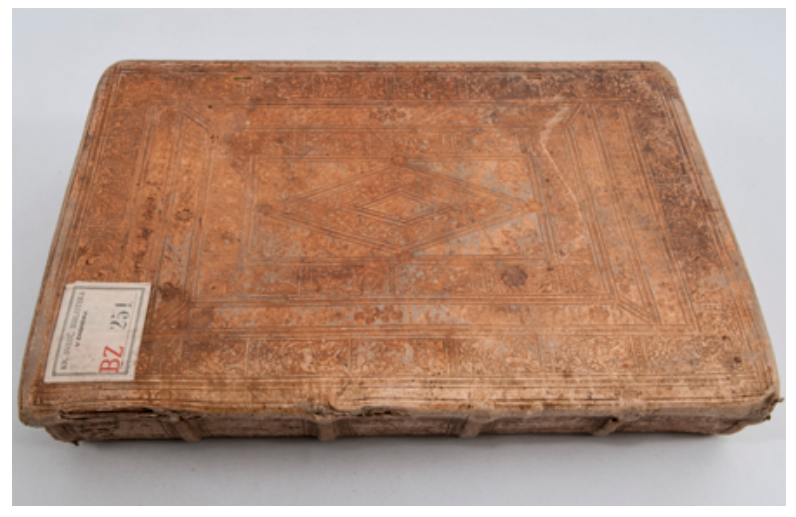

6a. Dn. loachimi Mynsingeri a Frundeck, iureconsulti clarissimi apotelesma sive corpus perfectum scholiorum ad quatuor libros Institutionum iuris civilis, nunquam antehac excusum, Joachim Mynsinger, Basileae, 1555, BZ 25, National and University Library in Zagreb

Dn. loachimi Mynsingeri a Frundeck, iureconsulti clarissimi apotelesma sive corpus perfectum scholiorum ad quatuor libros Institutionum iuris civilis, nunquam antehac excusum, Joachim Mynsinger, Basileae, 1555., (NSK, BZ 25)

against the use of green wood; its subsequent shrinkage can cause breakage of glass vessels or bring deformation to artefacts. The wooden parts of the case were joined together and lined with leather, wool or silk. If the wooden core was turned slightly large, an interlining of cotton fabric was inserted between the wood and the lining material to create a snug fit between the case and the artefact.

A case for a ewer or a similar object, designed to be stored upright, had to have a foot, turned from a single piece of wood. The core of the case was turned from one piece of wood that was cut after turning, producing two precisely fitting parts of the case. The compartment for the ewer's spout was usually made from two pieces of wood, attached to the main wooden form by gluing. The spout and other structurally weaker parts were reinforced by linen cloth, soaked in animal glue. The surface of the wood was further shaped by rasping to finish it. This was followed by lining the case with fabric or leather. Prediger gives a sequence of steps: the left half of the case and the foot were lined separately and then glued together. The right part of the case was lined next; the overlap of the leather lining could be used to make a flexible hinge. The covering of the exterior by leather or fabric followed. Prediger describes using multiple layers of leather to improve the stability of the case, skiving of the leather to reduce the thickness at joints, and care for making the joints less visible. Animal glue was used for structural attachment, while wheat starch was used for areas that needed less adhesive power: for example, the covering and lining. Sewing was done using hemp or linen thread, twisted by the craftsman to ensure the right strength of the thread. Threads were waxed or pulled through pitch to make them pliable and durable. A description of the gilding technique is also part of Prediger's book; the summary

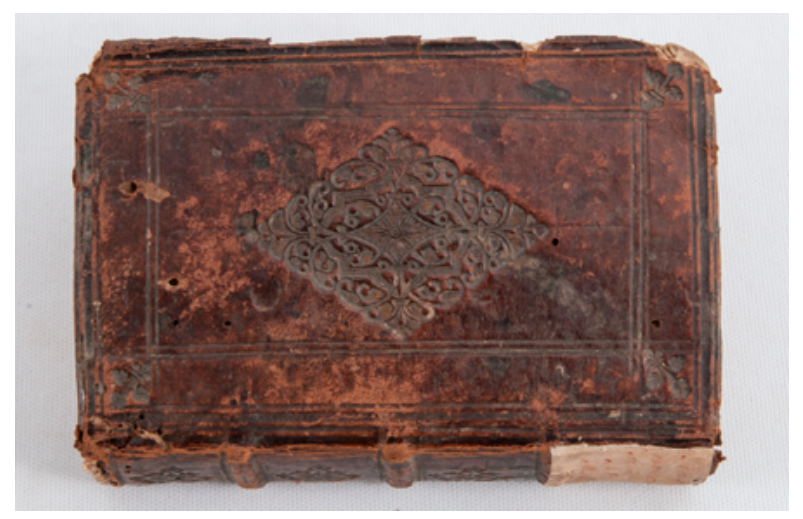

6b. Silii Italici poetae clarissimi de bello Punico secundo libri septemdecim, Silius Italicus and Tiberius Catius Asconius, Lugduni, 1578, BZ 356, National and University Library in Zagreb Silii Italici poetae clarissimi de bello Punico secundo libri septemdecim, Silius Italicus i Tiberius Catius Asconius, Lugduni, 1578., (NSK, BZ 356)

of the technique can be found in the Endnotes. ${ }^{28}$ Written in the $18^{\text {th }}$ century, Prediger's prescriptive text reflects the standardisation of bookbinding and case-making practices by this time, and needs to be taken critically and secondarily to the object-based research.

Despite their age and use, and the sensitivity of organic materials to relative humidity and temperature, the cases discussed above are still in good condition. Their shape is sometimes deformed, the clasps are not always intact, but their material essence has survived, and the cases remain functional. The exterior and interior layers, however, are often worn away by mechanical stress, transportation and frequent handling; the gilding and embossed decorations are often worn out. These observations are consistent with the research carried out by Weinberger, ${ }^{29}$ and her summary of the problems of preserving cases. At a general level, the problems can be grouped into three categories: 1) structural deformations and warping of the wood; 2) pest infestation by beetles and insects that feed on the wood, the glue layer, the leather exterior and the lining; 3) wear of the exterior and interior surfaces, and loss of gilding due to mechanical damage and handling.

\section{Cases from the set by Peter Kuster: Materials, Techniques and Condition}

To gain information about the materials and production techniques, the history of the cases and early restorations, the following investigations were carried out prior to conservation treatment.

X-radiography images (Seifert Isovolt mobile X-ray inspection system) were taken at the Kunsthistorisches Museum Wien. ${ }^{30}$ One leather sample was analysed by energy-dispersive X-ray microanalysis in the scanning electron microscope (SEM/EDX, Zeiss EVO MA15 at 
$20 \mathrm{kV}$ accelerating voltage and energy-dispersive X-ray detector Bruker Xflash $630 \mathrm{M}$ ) using back-scattered electrons (BSE). In addition, light microscopy was applied as a further examination method (Zeiss Axio Scope. A1, VIS und UV) ${ }^{31}$.

Microscopy imaging has enabled characterisation of the surface topography and a determination of the manufacturing techniques. A small leather sample was taken from the edge area of the lid on the basin's case, and a cross-section was made (Fig. 7a-c). The sample shows reddish-brown leather (1) covered with a black coating of approximately $100 \mu \mathrm{m}$ thick (2). This coating consists mainly of carbon black and therefore could not be dated. Above it is a thin layer of binder with bright UV fluorescence (3). Another black layer with Bologna chalk as filler (4) was applied to the surface of the leather. Our interpretation was that layers 2 to 4 were not original.

$\mathrm{X}$-radiography was useful to reveal the inner structure of the cases, which was hidden by the leather cover and silk lining. ${ }^{32}$ It was possible to distinguish the individual pieces of wood, thickness and density, the joints and reinforcements, and old repairs with nails, fillers and putties (Fig. 8a-c).

The acidity of the leather was not measured, because of the thick layer of wax. Investigations such as the determination of the tanning method or the measurement of the shrinkage temperature could not be carried out, due to shortage of time.

The investigations confirmed the cases to be contemporary with the silverware. The condition of the cases reflects their long history of use, as storage cases for ewer and basin with high relief decoration, evident from the wear and tear of the silk lining and the matching holes in the wood from the protruding parts of the ewer. The other changes to the materials - cracks in the wood, loose joints and detaching leather, to name a few - were caused by the environmental conditions in the past, and by physical forces: for example, from falling. The deformations found on the ewer and the basin are consistent with this damage to the cases, and could have resulted from the ewer falling or slipping from the basin. Previous restoration treatments, especially those aimed at structural stabilisation, have aged and were failing, while the excessive wax coating was unnecessary and changed the appearance of the leather.

\section{Ewer case, made in two halves}

The ewer case is $48.8 \times 17 \mathrm{~cm}$, weighing $1050 \mathrm{~g}$, made of a wooden core, covered in punched and embossed leather, lined with red silk satin, finished with metal clasps. The thickness of the wood runs from $3 \mathrm{~mm}$ for the walls to $7 \mathrm{~mm}$ for the joints. The fine lines visible on the radiograph of the spout and the handle suggest the wood was cut radially. There is a hole in the lower part of

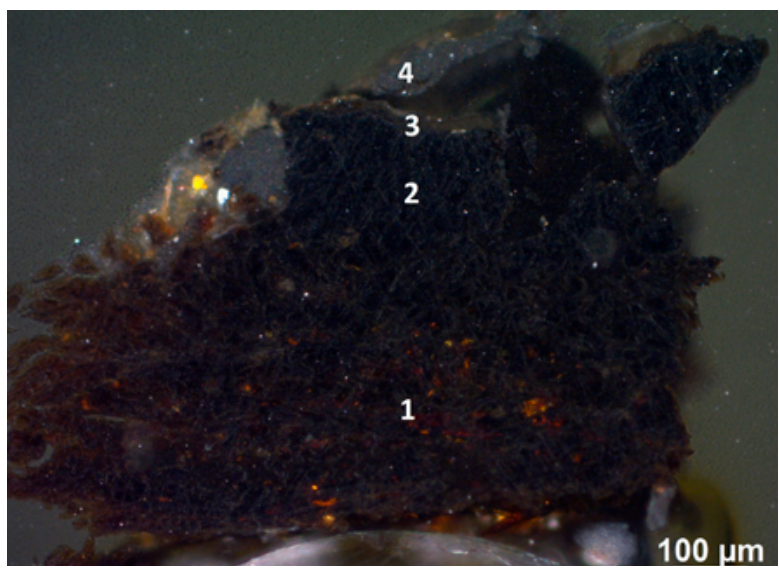

7a. Light microscopy of leather sample (Bundesdenkmalamt, Austria, R. Linke, 2019)

Svjetlosna mikroskopija uzorka kože (Bundesdenkmalamt, Austrija, R. Linke, 2019.)

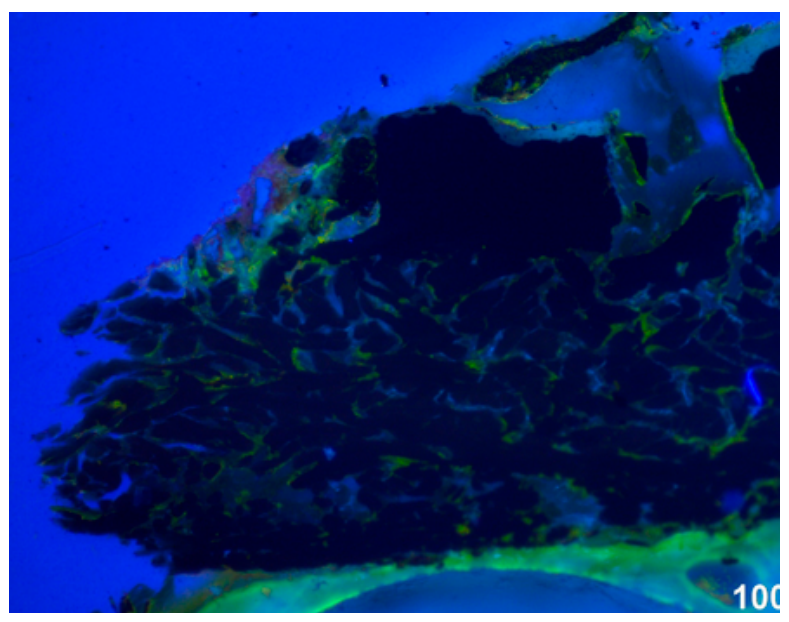

7b. Light microscopy of leather sample under UV light (Bundesdenkmalamt, Austria, R. Linke, 2019) Svjetlosna mikroskopija uzorka kože pod UV svjetlom (Bundesdenkmalamt, Austrija, R. Linke, 2019.)

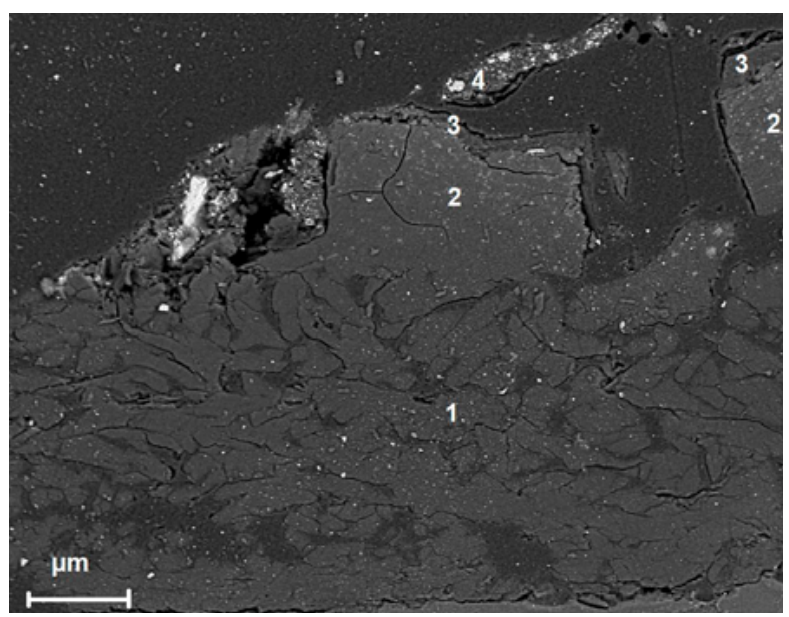

7c. Scanning electron-microscope image of leather sample (Bundesdenkmalamt, Austria, R. Linke, 2019)

Slika uzorka kože skenirajućim elektronskim mikroskopom (Bundesdenkmalamt, Austrija, R. Linke, 2019.) 


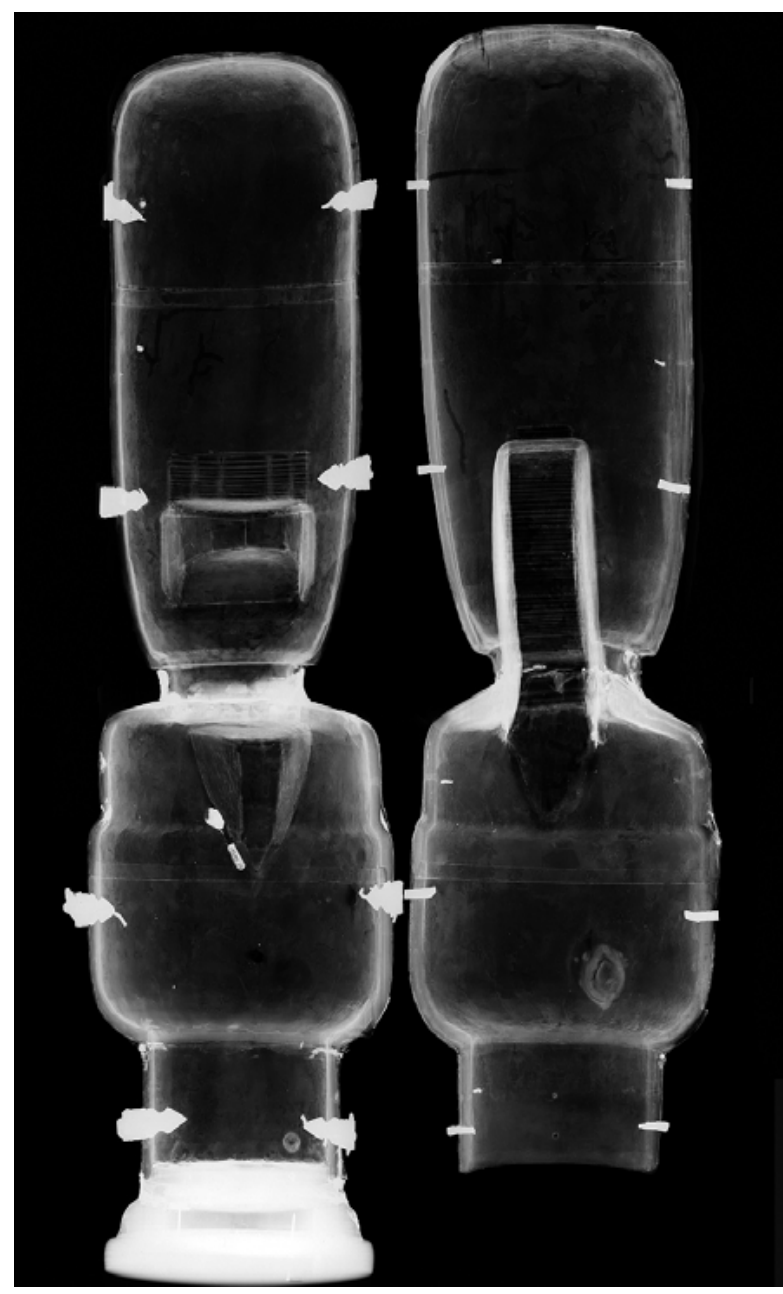

8a. Ewer case, X-radiography image (I. Slama, 2019)

Futrola vrča, RTG snimka (snimka: I. Slama, 2019.)

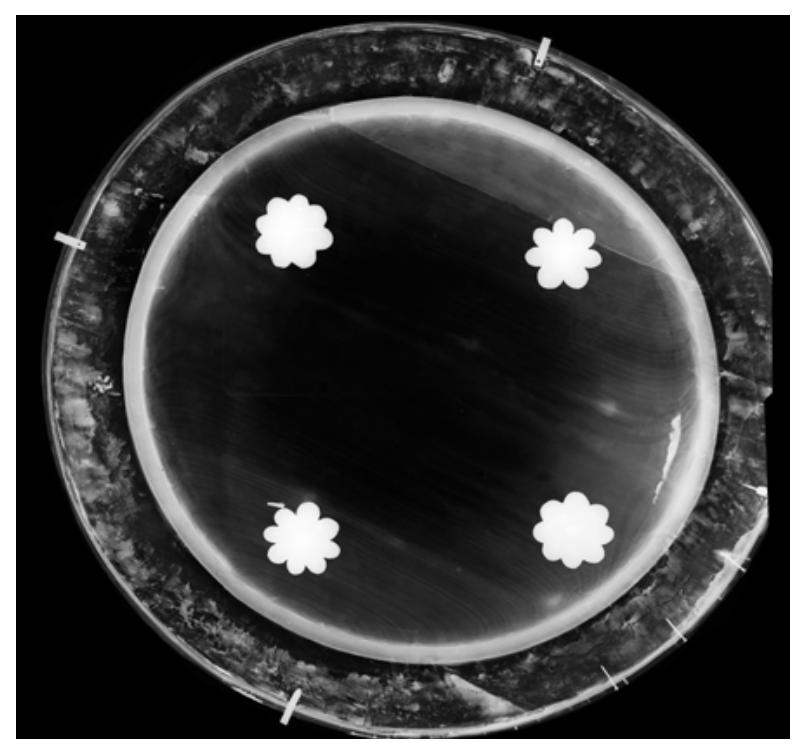

8b. Basin case, X-radiography image of the lid (I. Slama, 2019) Futrola umivaonika, RTG snimka poklopca (snimka: I. Slama, 2019.)

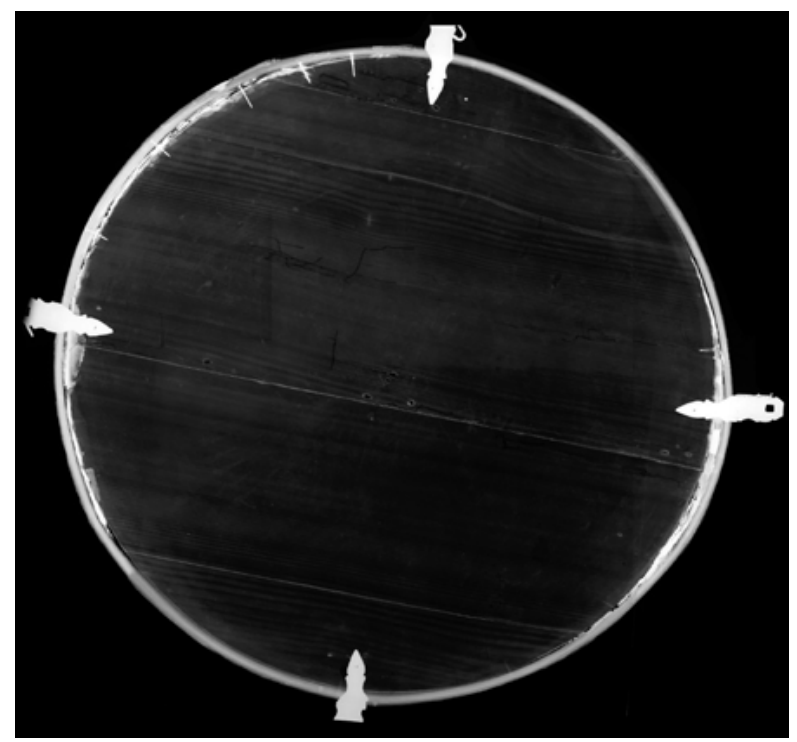

8c. Basin case, X-radiography image of the basin support (I. Slama, 2019)

Futrola umivaonika, RTG snimka nosača umivaonika (snimka: I. Slama, 2019.)

on the upper and lower parts of the case, and as straight lines on the spout and the handle (Figs 8a and 10a). The fine silk inner lining, as expected, produced low-contrast images. However, the multiple and lifted layers of the silk are visible in the cavity of the handle, where it is damaged (Fig. 10a).

The wear pattern of the silk lining (Fig. 1c) matches the shape and the decorative high-relief details of the ewer. Overall, the silk was found dirty from use, worn out, with numerous holes, detached from the wood in places, and missing on all edges of the case. Inside the handle recess the silk was damaged by pests; it had previously been leather pieces is clearly visible as double horizontal lines 


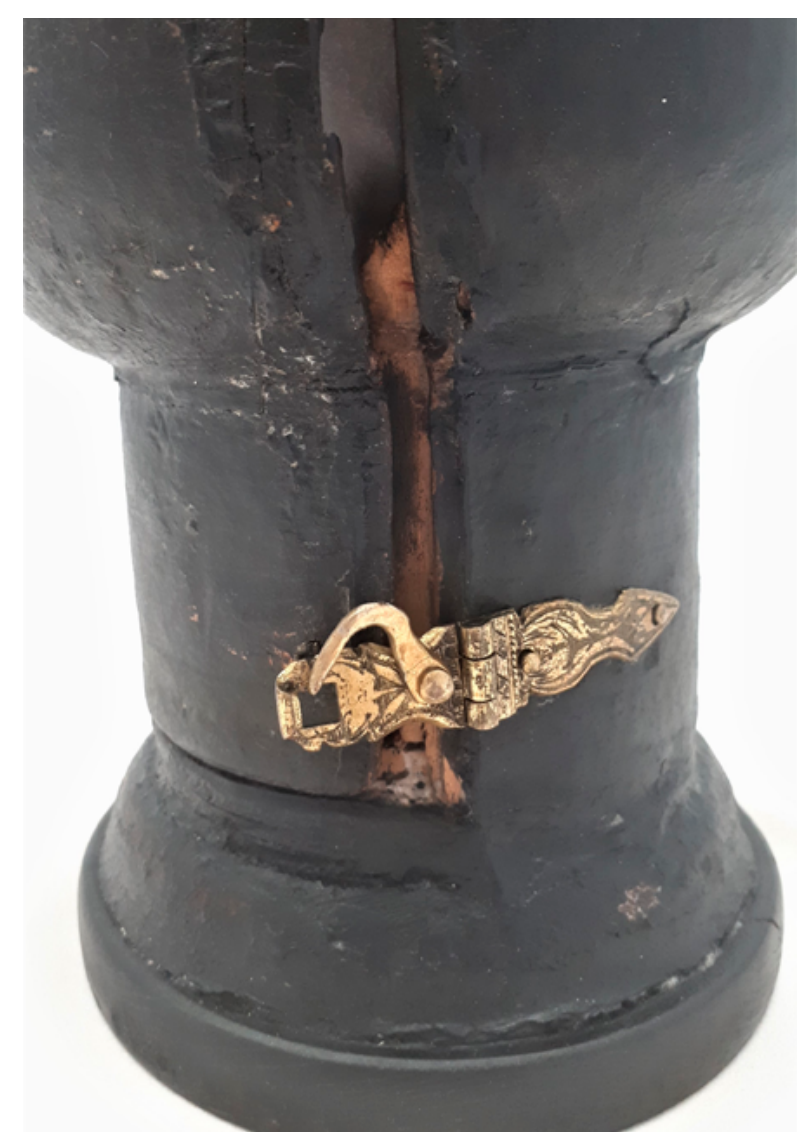

9a. Ewer case, detail, the wooden foot is not original, incomplete rebate, broken metal clasps, thick wax coating, before conservation, Peter Kuster, Nuremberg, c. 1550, Treasury of the Dubrovnik Cathedral, Croatia (V. Ljubić Tobisch, 2019)

Detalj futrole vrča, drvena noga nije originalna, nepotpuni preklop lomljene metalne kopče, debeli voštani premaz, stanje prije radova, Peter Kuster, Nürnberg, oko 1550., (snimka: V. Ljubić Tobisch, 2019.)

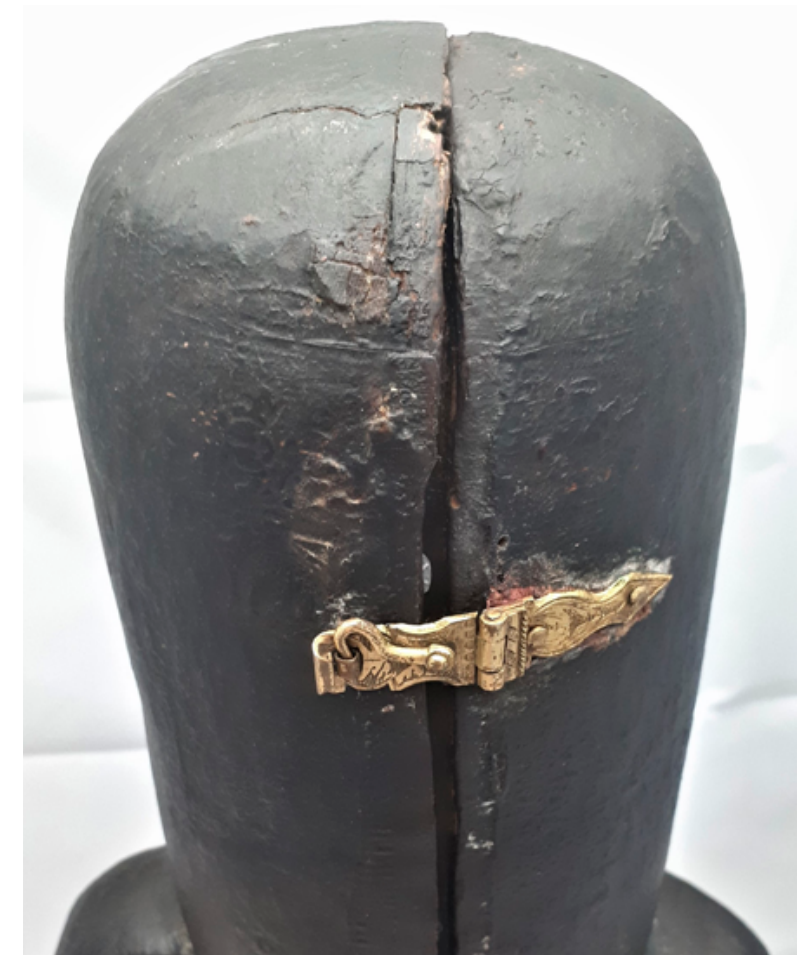

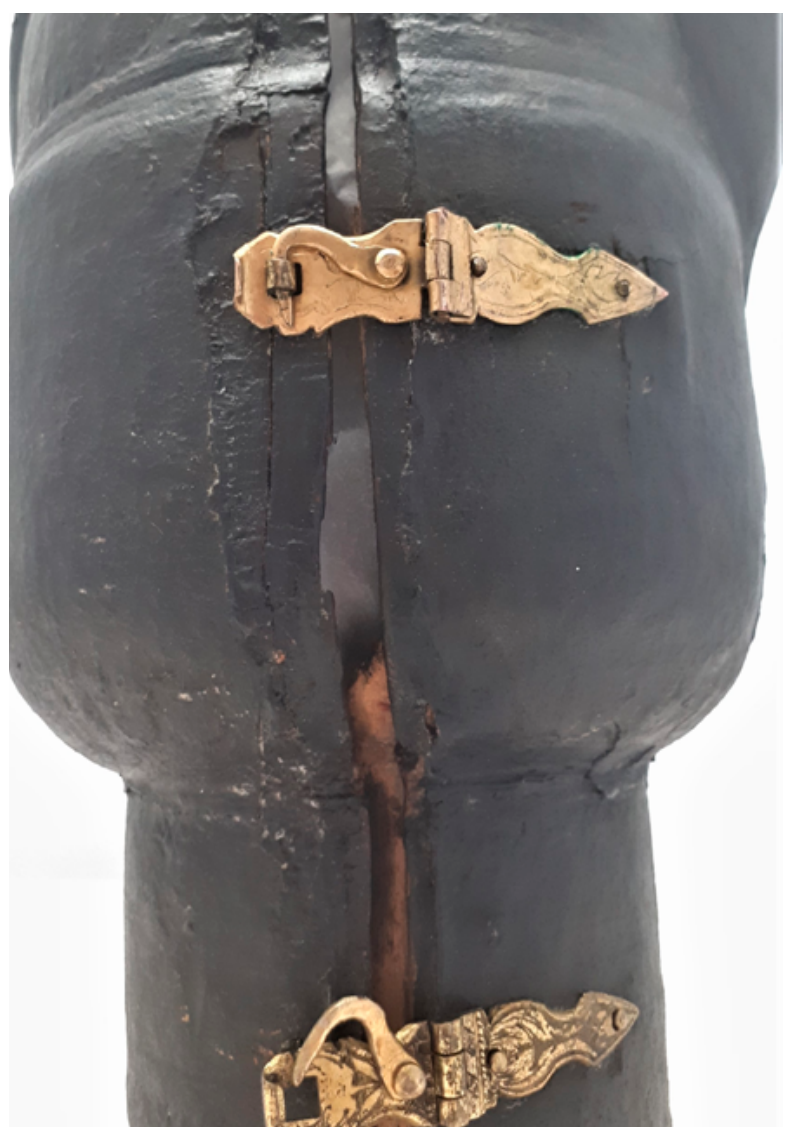

9b. Ewer case, detail, missing rebate and two styles of metal clasps, thick wax coating, before conservation, Peter Kuster, Nuremberg, c. 1550, Treasury of the Dubrovnik Cathedral, Croatia (V. Ljubić Tobisch, 2019)

Detalj futrole vrča, nepotpuni preklop, dva tipa metalnih kopči, debeli premaz od voska, stanje prije radova, Peter Kuster, oko 1550. (snimka: V. Ljubić Tobisch, 2019.)

9c. Ewer case, detail, 8-cm crack in the wood at the upper end, thick wax coating, before conservation, Peter Kuster, Nuremberg, c. 1550, Treasury of the Dubrovnik Cathedral, Croatia (V. Ljubić Tobisch, 2019)

Detalj futrole vrča, pukotina u drvu na gornjem dijelu od $8 \mathrm{~cm}$, debeli premaz voskom, stanje prije radova, Peter Kuster, oko 1550. (snimka: V. Ljubić Tobisch, 2019.) 


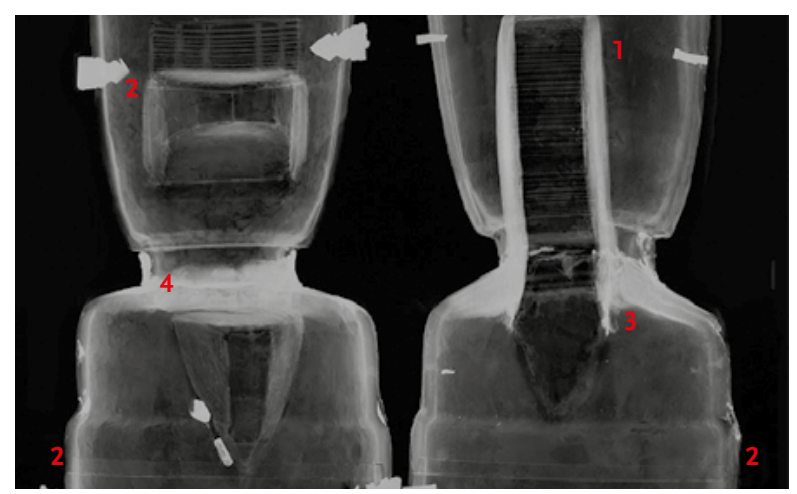

10a. Ewer case, detail: radially-cut wood is visible on the handle (1); arrangement of leather pieces is visible as double horizontal lines on the upper and lower parts of the case, on the spout and the handle (2); multiple and lifted layers of damaged silk lining appear as a bundle in the handle recess (3); old restoration putty (4) (I. Slama, 2019)

Detalj futrole vrča: radijalno izrezano drvo vidljivo na dršci (1); raspored komada kože vidljiv je kao dvostruke vodoravne linije na gornjem i donjem dijelu kućišta, na izljevu i ručki (2); višestruki i podignuti slojevi oštećene svilene podstave pojavljuju se kao svežanj u udubljenju ručke (3); stari restauratorski kit (4) (I. Slama, 2019.)

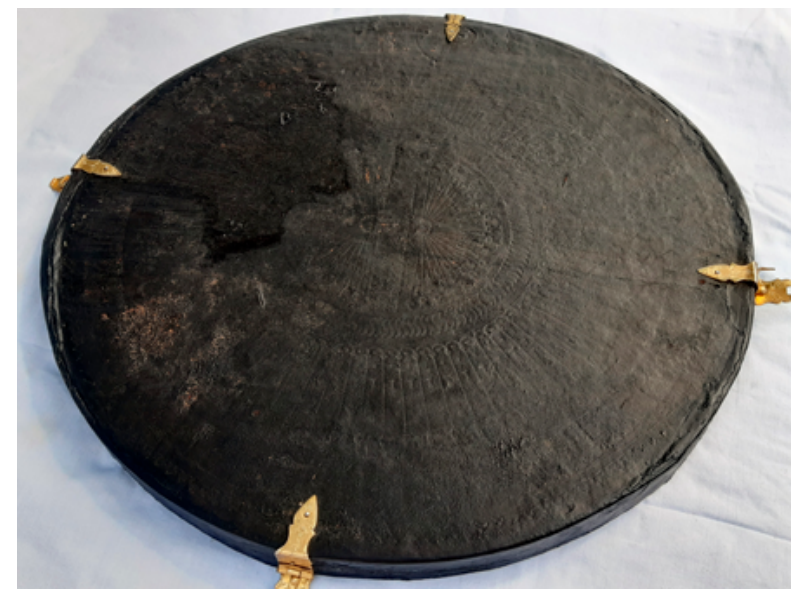

11a. Basin case, during treatment. Partial removal of wax and recovery of original punched surface

(V. Ljubić Tobisch, 2019)

Umivaonik, stanje tijekom radova. Djelomično uklonjen vosak i obnovljena originalna puncirana površina (snimka: V. Ljubić Tobisch, 2019.)

repaired using animal glue. The glue has aged, causing strain and staining the silk. The interior of the foot displayed only fragments of the original silk lining. ${ }^{33}$ Despite such losses, the remaining silk fabric was found overall to be structurally stable.

Most of the leather was found in good condition but heavily coated in sticky wax mixed with black pigment, which had altered the cases' appearance by obscuring the punched decoration (Figs 1a-b, 2 and 9a-c). This was consistent with the SEM/EDX analysis. Brown putty was

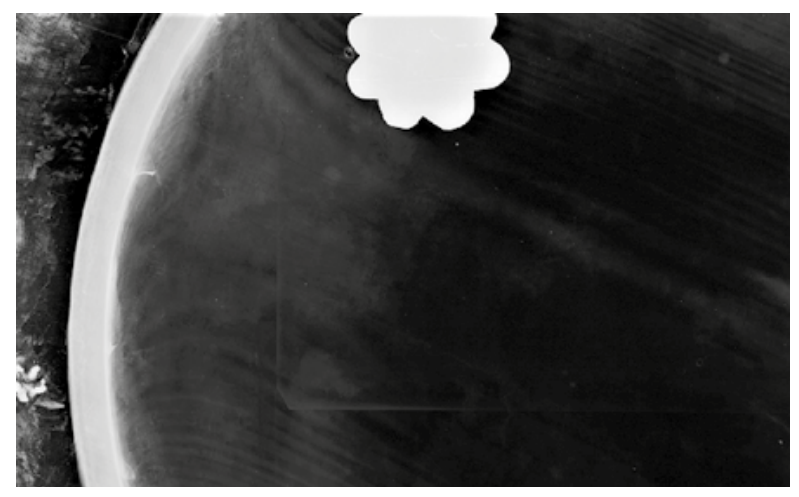

10b. Basin case, detail, X-radiography image of the basin support. An outline of rectangular shape, which looks like a piece of paper or card, is visible (I. Slama, 2019)

Futrola umivaonika, detalj, rendgenska snimka nosača bazena. Vidljiv je obris pravokutnog oblika koji izgleda kao komad papira ili kartona (I. Slama, 2019.)

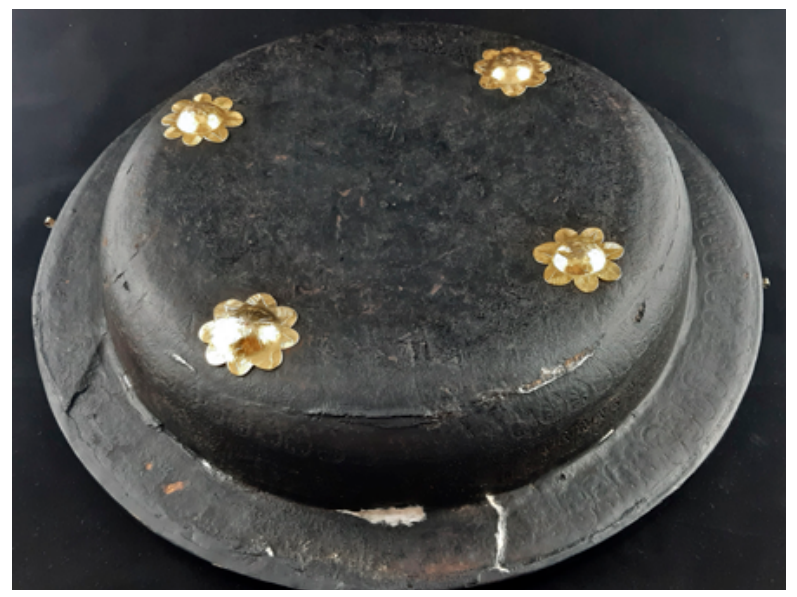

11b. Basin case, during treatment. Partial removal of wax, and repair of structural cracks in the leather with Japanese paper and adhesive (V. Ljubić Tobisch, 2019)

Umivaonik, stanje tijekom radova. Djelomično uklonjen vosak i sanacija strukturalnih pukotina na koži japanskim papirom i ljepilom (snimka: V. Ljubić Tobisch, 2019.)

applied excessively in previous restoration treatments to repair joints and to infill cracks in the leather. The putty is clearly visible on the radiograph, bright because of its density. The putty was found to be failing structurally, and its plastic-like appearance made it unsympathetic to the original surfaces. The leather at the joints was found to be detached from the wood. The metal clasps in the closed state caused additional tension to the case. Some clasp hooks were found incomplete and had lost their function. Differences in size, shape and surface design 

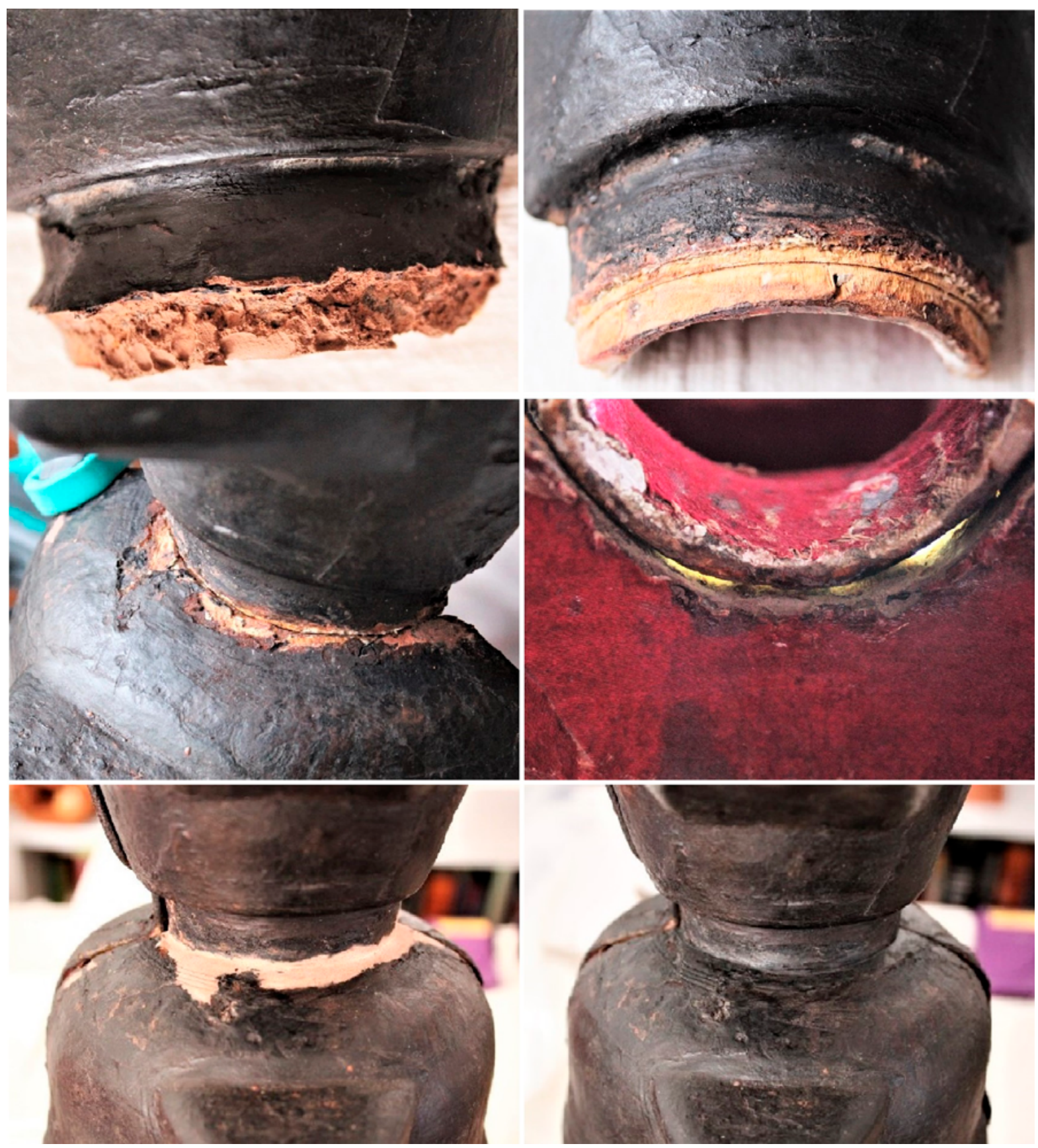

12. Ewer case, conservation treatment. Repair of joints and adjoining areas using epoxy resin, inpainted with watercolour paints and wooden stains; stabilisation of structural gaps using Japanese paper and acrylic adhesives, retouched with acrylic paints (V. Ljubić Tobisch, 2019) Futrola vrča, konzervatorsko-restauratorski radovi. Popravak spojeva i okolnog područja epoksidnom smolom, bojanje akvarelnim bojama i bajcom; stabilizacija strukturalnih rupa japanskim papirom i akrilnim ljepilom, retuširano akrilnim bojama (snimka: V. Ljubić Tobisch, 2019.)

were also evident, indicating that the clasps had been renewed over time.

\section{Basin case, made in two parts: basin support and lid}

The round basin case is $53 \times 15 \mathrm{~cm}$, weighing $2.8 \mathrm{~kg}$, made of a wooden core, covered in punched and embossed leather, lined with red silk satin, with metal clasps. Both parts of the basin case - the basin support and the flat lid - are made of planks, which appear to be radially cut (Fig. 8b-c). Wooden pins are clearly visible on the radiograph of the base, a sign of a butt joint construction. ${ }^{34}$ The rim of the basin support, made from a thin, narrow wooden ring, is not original; it is secured by nails and restoration putty. On the lid, the rim was found to be incomplete, the gap between the rim and the well previously filled by putty. The radiography image clearly shows the channels in the wood from previous pest activity. On the basin support there is an outline of an incomplete rectangular shape, which looks like a piece of paper or card, located underneath the leather (Fig. 10b). It is not visible in daylight. 


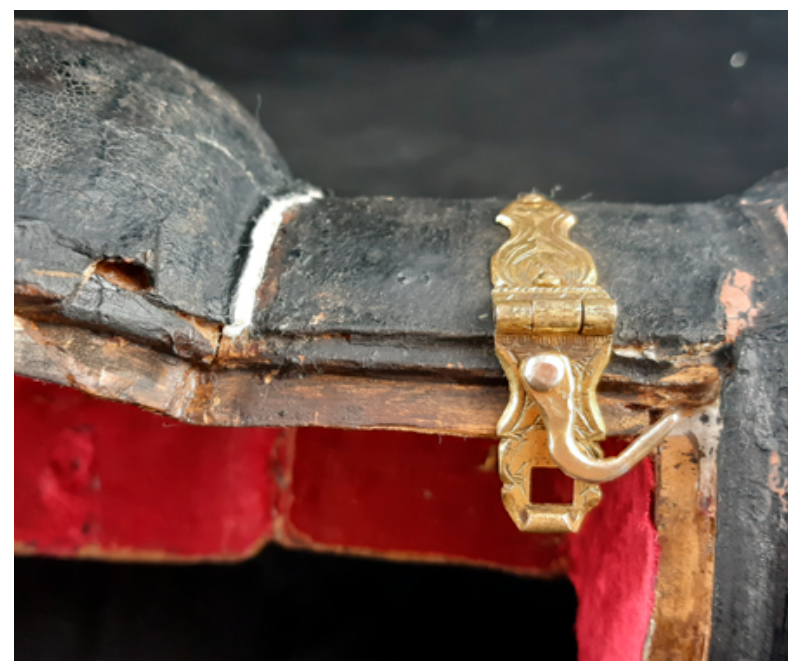

13. Ewer case, detail, showing cracks in the leather being repaired with Japanese paper and adhesive (V. Ljubić Tobisch, 2019) Futrola vrča, detalj, pukotine na koži koje se saniraju japanskim papirom i ljepilom (snimka: V. Ljubić Tobisch, 2019.)

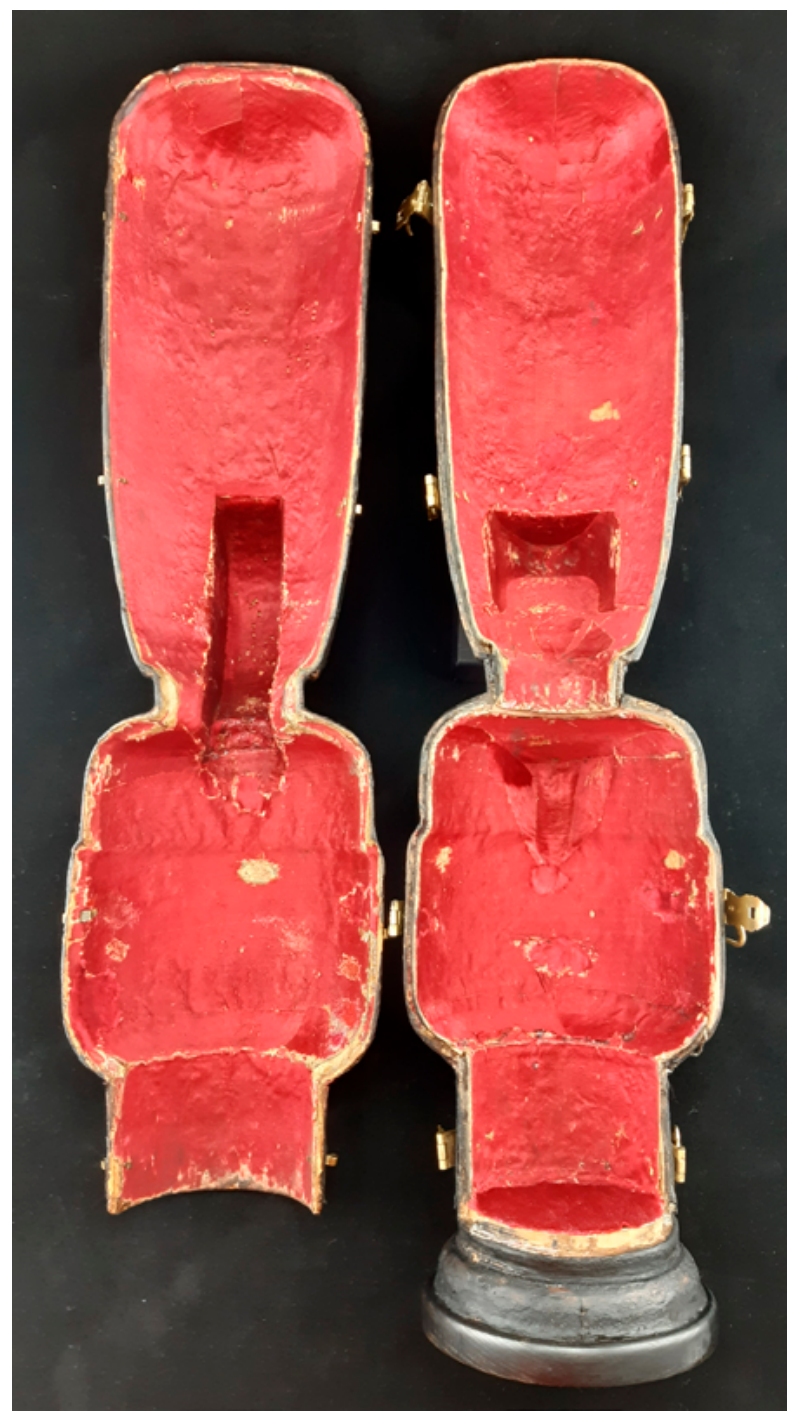

14. Ewer case, interior, after conservation (V. Ljubić Tobisch, 2019) Futrola vrča, unutrašnjost, stanje nakon radova (snimka: V. Ljubić Tobisch, 2019.)

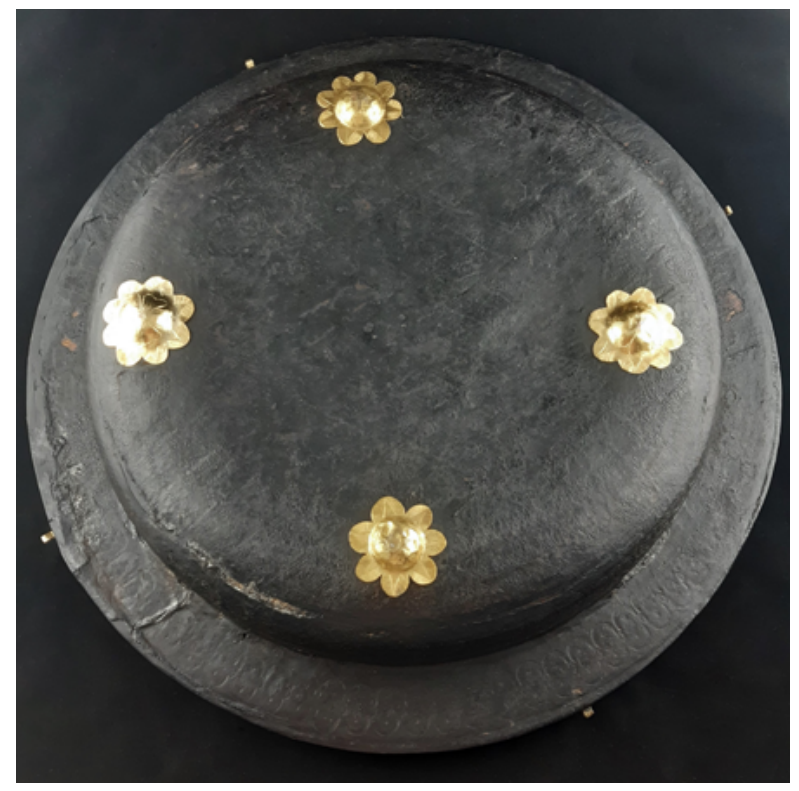

15. Basin case, punched and embossed leather after treatment ( $\mathrm{V}$. Ljubić Tobisch, 2019)

Futrola umivaonika, bušena i gravirana koža nakon radova (snimka: V. Ljubić Tobisch, 2019.)

Originally the red silk satin covered the whole of the interior of the basin support, extending all the way over the wide lip and to the edge of the rim. The silk is now present only on the bottom of the basin support; it has been abraded around the edges, and stained by animalbased glue. Previous restoration covered the remnants of the silk in a fine fabric mesh and coated it with beige filler (Figs $8 c$ and 16a).

On the flat lid, the silk lining was in good condition, apart from a tear in the middle and small stains from animal-based glue. The nails currently securing the rims on both halves of the basin case are not original. Nails of the Renaissance period would have left stains: green from brass, brown from iron. The absence of stains suggests that originally the cases were only glued and pinned, but not nailed. Like the ewer case, the basin case was heavily coated with pigmented wax. Fragments of gold leaf were found on the lid, on the surface of the waxed leather. However, SEM/EDX did not identify gold in the sample analysed, and no gilding was found after the removal of wax from the surface; perhaps it was lost due to handling or over-cleaning in the past. The gold particles could also have come from another artefact in storage.

\section{Conservation treatment}

Conservation treatment focused on the preservation of material evidence of use of the cases, and on the recovery of the original surfaces of the leather and silk satin. The treatment prioritised structural stabilisation of the wood, leather and silk-satin lining, and reduction of the waxy coating. ${ }^{35}$ 


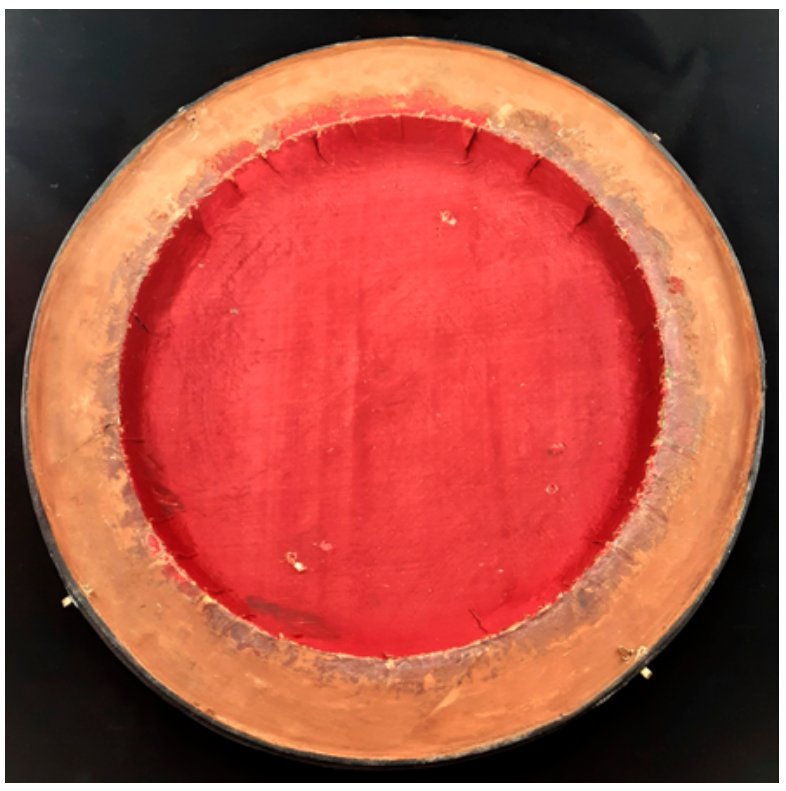

16a. Basin case, interior of the basin support, after conservation (V. Ljubić Tobisch, 2019)

Futrola umivaonika, unutrašnjost bazenskog nosača, stanje nakon radova (snimka: V. Ljubić Tobisch, 2019.)

On both cases, the thick coating of pigmented wax was reduced by repeated swabbing with white spirit (Benzin 100/140) and toluene. ${ }^{36}$ This was successful in revealing the original leather surfaces (Fig. 11a-b). In places a white haze appeared on the leather, likely the result of migration of free fatty acids from aged wax, and it may reappear in the future. ${ }^{37}$

The dismantled metal clasps were cleaned in a warm decoction of soapwort root (Saponaria officinalis) ${ }^{38}$. Cleaning was carried out only with soft brushes. Finally, the surface was wiped clean of any remaining sulphide layers with a cotton cloth, sparingly adding whitening chalk and rouge, ${ }^{39}$ and lightly polished. All metal elements that could not be removed were isolated from the leather by an intermediate layer of foil and mechanically cleaned in situ with chalk.

\section{EWER CASE}

The 8-cm crack in the wood was repaired with epoxy resin paste: Aralditeâ Renpaste SV 427-2 and hardener Ren HV 427-1. ${ }^{40}$ Loose joints in the wood were secured by rabbit-skin glue. Missing parts of the rebate were made of poplar wood and inpainted with watercolour paints. Failed old putty was removed. Joints and their adjoining areas were secured using the same epoxy resin, inpainted with watercolour paints and wooden stains (Fig. 12). Smaller structural gaps in the leather, especially around the joints, were stabilised with Japanese paper of various weights adhered with a mix of acrylic adhesives, Lascaux 498 $\mathrm{HV} / 303 \mathrm{HV}(2: 1)$, and additionally retouched in acrylic paint. (Figs $12 \mathrm{~b}$ and 13$){ }^{41}$

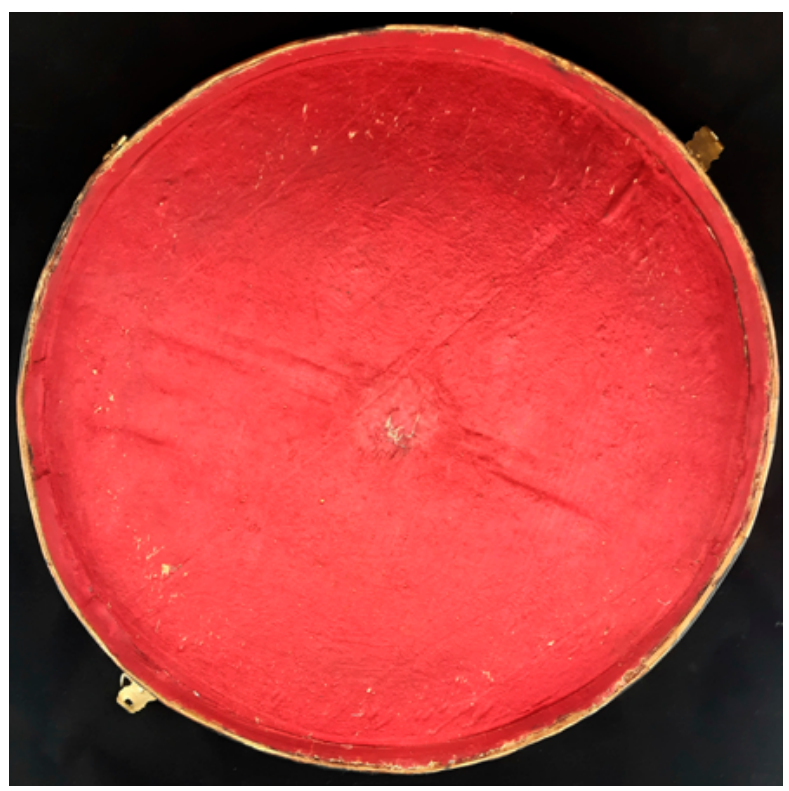

16b. Basin case, interior of the lid, after conservation (V. Ljubić Tobisch, 2019)

Futrola umivaonika, unutrašnjost poklopca, stanje nakon radova (snimka: V. Ljubić Tobisch, 2019.)

Despite the excessive loss, it was viewed important to preserve the original silk lining, to keep it visible and avoid covering it with conservation materials, for example with the silk crepeline overlay that can sometimes be used to stabilise aged textiles. The silk lining was cleaned by low vacuum suction, followed by swabbing with ethanol. This returned the lustre to the silk. Animal-glue stains in the handle recess were reduced mechanically by scalpel, followed by swabbing with deionised water, and the excess water removed by blotting paper. This was successful in cleaning and reshaping the fragmented lining to be able to adhere it to the wood. Loose edges of the silk lining were reattached to the wood using ethylene vinyl acetate in the form of the EVAbased adhesive Beva film 371, activated by heat at $65^{\circ} \mathrm{C} .{ }^{42}$ The most noticeable and structurally weak areas of loss were infilled with new silk satin, dyed to colour (Fig. 14). Some of the holes were infilled with Japanese paper and inpainted with acrylics. Both types of infills were adhered to the wood using Beva film 371, activated by heat at $65^{\circ} \mathrm{C}$. Acrylic paints were further used to retouch the newlyadded silk and paper pieces. ${ }^{43}$ Some of the smaller and structurally stable holes were left untreated to preserve the appearance of a used object. The metal clasps were treated in the same way as the metal parts on the basin case.

\section{TREATMENT OF THE BASIN CASE}

On the basin support, the detaching leather was adhered to the wood with Lascaux $498 \mathrm{HV}$. On the rim and curved areas, the lifting and fragile leather was stabilised using rolls of Japanese paper, adhered with Lascaux 498 
HV/303HV (2:1). On the silk lining, the drops of animal glue were removed mechanically. The silk was further cleaned by swabbing with ethanol. The fabric mesh from previous restoration was kept as it is, the abraded edges of the silk lining were secured to the wood with a mixture of Lascaux $498 \mathrm{HV} / 303 \mathrm{HV}$ (2:1).

On the flat-shaped lid, the missing parts of the rim were rebuilt using balsa wood, adhered with rabbit-skin glue. The old putty in the gap between the sidewall and the well was removed mechanically and the gap secured by infilling with rolls of Japanese paper of various weights adhered with a mix of acrylic adhesives Lascaux 498 HV/303HV (2:1) and retouched in acrylic paint (Fig. 15). The silk lining was cleaned by swabbing with ethanol (Fig. 16a-b). Animal-glue stains were reduced using water poultices, and the tear in the silk was closed by securing the lifting edges of the silk to the wood using Beva film 371 , activated by heat at $65^{\circ} \mathrm{C}$.

\section{Conclusion}

Considering the cases and silverware as an ensemble was useful for assessing the historic significance of the lavabo set, and for understanding its material condition as a whole. The conservation treatment was successful in achieving its main goal of preserving the material evidence of the use of the cases, and focusing on structural stabilisation of the wood, leather, and silk lining, and recovery of the original surfaces. The wax coating was significantly reduced to recover the punched and embossed leather surface. The silk lining, despite significant losses, remains accessible, and its appearance has been reinstated. Infills in the silk were minimal and applied only to visually distracting areas. The treatment is reversible.

\section{Endnotes}

1. HERMANCK, 1978, IX, 70. CHIPPS SMITH, 1983, 4, KAHSNITZ, WIXOM, 1986, 19-20.

2. Two examples: the case for Jamnitzer's Merkelscher Aufsatz - Merkel's Table Piece - in Staatsarchiv Nürnberg, Stadtrechnungsbelege (Rep. 54 a II) Nr. 124 and the original document detailing its cost and materials. The case for the Schlüsselfelder Ship in the collection of the Germanisches Nationalmuseum bears the date 1503, suggesting it was made at the same time as the ship, https://objektkatalog.gnm.de/wisski/ navigate/65609/view [15/10/2021].

3. On value assessment methodologies in heritage preservation, see: MEUL, 1048-1053, https://www.icom-cc-publicationsonline.org/1983/Safeguarding-the-significance-of-ensemblesvalue-assessments-in-Risk-Management-for-Cultural-Heritage [11/10/2021], and BROKERHOF, KEMP, BÜLOW 'Value Management Scan: setting priorities in management and care of collections', in ICOM-CC18th Triennial Meeting Copenhagen
The conservation treatment was greatly assisted by the material analyses, X-radiography, light microscopy and SEM/EDX. The project yielded new information about the Renaissance materials and production techniques of Futterale close-fitting cases. It gained a new understanding of the history of previous restorations, the strengths and weaknesses of the materials and construction of such historic cases. The cases will be preserved and exhibited alongside the silver masterpiece by Peter Kuster. A comparison of the works of Peter Kuster and Wenzel Jamnitzer would benefit from a technical study of the original leather cases, associated with the silverware. The strong resemblance between the case for the Merkelscher Aufsatz (Merkel's Table Piece) and the case for the ewer by Kuster deserves further investigation.

Historic cases such as these, with their light construction and close-fitting shape, provided protection for the valuable artefacts for a long time. Today they serve as an example of sustainable and long-lasting packaging and make us reassess our approaches to the protection of cultural treasures without the use of throwaway products.

\section{Acknowledgements}

The authors thank the Kunsthistorisches Museum Wien and Ina Slama for the X-ray analyses; Robert Linke and the Federal Monuments Authority Austria (Bundesdenkmalamt) for the cross-section analyses of leather; Sylvia Birkušová for assisting in dyeing the silk fabric; Jae Seo Park for assisting with retouching; Chris Clouter for advice on infilling materials; Anna Hammerschmied for stabilisation of wood components. We are especially thankful to Joosje van Bennekom for sharing the conservation report and images of the centrepiece by Wenzel Jamnitzer in the collection of the Rijksmuseum.

Preprints, edited by J. Bridgland. Paris: ICOM. https://www.icomcc-publications-online.org/1699/Value-management-scan--Settingpriorities-in-management-and-care-of-collections [11/10/2021]. 4. KRIS, 2012/1926, 57-58; PELC, 2004, 292; SCHÜRER, 2002, 185-188.

5. 'Making Marvels: Science and Splendor at the Courts of Europe', The Metropolitan Museum of Art in New York, USA (Nov-182019-Mar-01-2020), https://www.metmuseum.org/exhibitions/ listings/2019/making-marvels-science-splendor. Investigation and conservation treatment of the lavabo set is discussed in LJUBIĆ TOBISCH, 2020; LJUBIĆ TOBISCH, LINKE, 2020.

6. BOHR, 2001, 190-261. Bohr describes the passion for collecting and patronage of the papal family Chigi (Pope Alexander VII Chigi (b. 1599, Pope 1655-67) of the cathedral in Siena. There, as in many other churches, precious liturgical objects were kept in the sacristy, which served as a treasury. According to the archives, the reliquaries were protected from damage and dirt with 
cases made of gold-printed red leather, and cases made of crimson velour. Not only the goldsmith's work, but other objects, for example, those made of rock crystal, were kept in solid cases. Protective cases, made of red leather, decorated with embossed stars, flower medallions and wickerwork pattern, are still preserved with the set of rock-crystal objects.

7. PELC, 2004, 292. The goldsmith's mark of Peter Kuster was discovered and decoded by Karin Tebbe.

8. AUER, RAUCH, SANDBICHLER, SEIPEL, 2006, 73; KAYSER, 2006, 45-61.

9. PELC, 2004, 293.

10. KOEPPE, 2020, 68.

11. For investigation of the technique and its significance in 16th-century Europe, see H. SMITH, BEENTJES, 2010.

12. https://ernstkris.wordpress.com/1921-1929/ (13/4/2020); BARTELMEß, 1963-1964, 259.

13. BARTELMEß, 1963-1964, 258-259, Hans Lobsinger, goldsmith and inventor (c.1510-1584.) Among other things, Lobsinger made spinning wheels, mills and various tools for other craftsmen, etched and prepared paints and chemicals, and made musical instruments. According to Lobsinger's patent application, he could make metal casts (life casts) of animals and plants in sand mould. 14. FRANKENBURGER, 1901, 6: on 19 December 1549 the city council demanded an explanation from Peter Kuster for using the same patterns and moulds as Wenzel Jamnitzer. This complaint, which probably came from Jamnitzer, might be attributed to the use of the press, which Lobsinger made for both goldsmiths in a similar form.

15. SCHÜRER, 2002, 185-188; PELC, 2004, 292; SPENLÉ, 2014, 40. The basin in Dubrovnik shows similarities in decoration and technique to the basin by Jamnitzer in the Musée du Louvre.

16. KOBLER, 2016, Futteral, Reallexikon zur Deutschen Kunstgeschichte, https://www.rdklabor.de/wiki/Futteral [20/5/2021]. 17. MÜLLER, 1998, 6-7.

18. DAVIES, 2006, 94-102: different techniques of making cuir bouilli leather are discussed by Davies. LINGWOOD, 1995: experimental reconstructions of cuir bouilli objects by a group of leather conservators and craftsmen suggest that the leather used would be half- or fully tanned. CHESHIRE, 2014, 41-76: experimental research by Cheshire suggests that the cuir bouilli was most likely a boiled raw hide, and not boiled leather. All of these methods are related by their use of water and moulding techniques, as explained by Davies: 'The familiar leather moulding techniques such as embossing and lasting rely on the use of mild heat and water to manipulate the properties of leather. These moulding and shaping techniques exploit the plastic character of vegetable-tanned leather when it is softened by water. When water is applied to leather it becomes malleable and easy to mould and it will retain this moulded shape or ornamentation when it dries. The ability of leather to do this derives from the action of warm water on the fibrous structure of its collagen chains and on the thermoplastic characteristic of vegetable-tanned leathers. However, once the process of moulding leather in this way is complete, and the object is dried, the structure of the leather is unaltered, and it remains flexible unless coated with a stiffening medium or mounted on a backing material.'

19. Further information about the boiled-leather technique and leather degradation can be found on the AIC Conservation Wiki, at https://www.conservation-wiki.com/wiki/BPG_Book_ Decoration\# Modeled-leather, and at https://www.conservation-wiki.com/wiki/BPG_Animal_Skin_and_Leather\#Leather_ Degradation [21/5/2021].

20. Copyright Photography Department Rijksmuseum Amsterdam. 21. Mannerism, also known as Late Renaissance, is a style in European art that originated in Italy around 1520 and lasted until the early 17 th century.

22. VAN BENNEKOM, 2018, 47. On Moroccan leather, see CAMBRAS, 2006, 31: leather from Moroccan goats is coarse-grained compared to leather from European goats. The term 'morocco leather' has come to include all coarsely-grained goatskins. 23. Staatsarchiv Nürnberg, Stadtrechnungsbelege (Rep. 54 a II) Nr. 124, 20 December 1549. ,80 Gulden dem Futtermacher für das futer lawt seiner zettel sambt dem Ledern Sack'. The case maker received 80 guilders for the production of this case. The price included the cost of materials and various services of other craftsmen, such as wood carving or the manufacture and gilding of the metal clasps.

24. On goldsmiths' workshop practices: SMITH, 2007, 32-57, and CHIPPS SMITH, 1983.

25. For bookbinding techniques, materials and tools that are relevant to the making of cases, see CAMBRAS, 2006.

26. KOBLER, 2016, https://www.rdklabor.de/wiki/Futteral [20 May 2021].

27. PREDIGER, 2006 (1764), 124-127.

28. PREDIGER, 2006 (1764), 67-72. Prediger's description of the gilding technique applies to books and cases. The calfskin or sheepskin leather was first coated with animal glue and, after it had dried, was evenly coated with pure egg white applied by natural sponge. After the egg white dried, the leather surface was greased with lard and rose pomade ('rosenpomade' - a mixture of rose oil and rose water), and the gold leaf was laid over it. The coating by egg white had to dry between applications, otherwise the gold leaf would adhere to the stamps during stamping, or the gilding would get a dull appearance. The last layer of egg white was left slightly moist before the surface was additionally treated with lard, and gilded. Egg white served as a barrier and glue at the same time. Without egg white the gold would not stay attached; it also protected the leather from staining during lard application. Prediger stresses the importance of applying the egg white correctly to avoid cracks or detachment of gold leaf. When such problems appear, Prediger advises using warm stamps over the gilded areas. High temperature regenerates the egg white, and this brings adhesion. The gilding stamps were divided into the following groups: fillets, decorative stamps, bow stamps, scroll stamps, and letter stamps. Each stamp had to be made for rightand left-handed application so that the ornament could be set in both directions in relation to the centre.

29. WEINBERGER, 1998, 52-57. 
30. X-radiography was carried out in the painting conservation department of the Kunsthistorisches Museum Vienna, with the assistance of Ina Slama.

31. SEM/EDX and microscopy analyses were carried out at the Natural Science Laboratory of the Federal Monuments Authority Austria in Vienna (Bundesdenkmalamt Wien) by Robert Linke.

32. More information on application of radiography to investigation of cultural heritage can be found in BROOKS, O'CONNOR, 2007. 33. More images can be found in DOVGAN NURSE, LJUBIĆ TOBISCH, 2021.

34. VEROUGSTRAETE, 2015, 46, 49. http://org.kikirpa.be/frames/ files/assets/basic-html/toc.html.

35. KITE, THOMSON, 2006.

36. Varnishes and Surface Coatings: Wax as Surface Coating, 2021. Paintings Group Wiki American Institute for Conservation (AIC). https://www.conservation-wiki.com/wiki/Varnishes_and_ Surface_Coatings:_Wax_as_a_Surface_Coating [11/10/2021]. 37. White Surface Hazes, 2019. Paintings Group Wiki American Institute for Conservation (AIC). https://www.conservation-wiki. com/wiki/White_Surface_Hazes [2/6/2021].

38. When the soapwort root is boiled in water, it produces a foamy liquid that can dissolve fats and grease. The dried and

\section{References}

ALFRED AUER, MARGOT RAUCH, VERONIKA SANDBICHLER, KATHARINA SEIDL, Die Entdeckung der Natur, Naturalien in den Kunstkammern des 16. und 17. Jahrhunderts, Vienna, 2006.

ALBERT BARTELMEß, Hans Lobsinger und seine Erfindungen, Mitteilungen des Vereins für Geschichte der Stadt Nürnberg, (1964), 256-264

PAULA ARTAL-ISBRAND, So Delicate Yet So Strong and Versatile - the Use of Paper in Objects Conservation, Journal of the American Institute for Conservation 57, 2, (2018), 1-15

JOOSJE VAN BENNEKOM, Wenzel Jamnitzer's Centrepiece and the Goldsmith's Secret, The Rijksmuseum Bulletin, 66 (2018), 44-67. MICHAEL BOHR, Der Chigi-Schatz im Dommuseum zu Siena. Sammelleidenschaft und Mäzenatentum einer päpstlichen Familie, Mitteilungen des Kunsthistorischen Institutes in Florenz, 45, (2001), 190-262

AGNES BROKERHOF, JANIEN KEMP, ANNA BÜLOW, Value

Management Scan: setting priorities in management and care of collections, ICOM-CC18th Triennial Meeting Copenhagen Preprints, Paris, 2017. https://www.icom-cc-publications-online.org/1699/ Value-management-scan--Setting-priorities-in-managementand-care-of-collections [11 October 2021]

MARY BROOKS, SONIA O'CONNOR, X-Radiography of Textiles, Dress and Related Objects, Routledge, 2007

JOSEP CAMBRAS, Handwerk Buchbinden: Schutz- und Buchumschläge; Techniken und Herstellungsprozesse, Bern/Vienna, 2006.

EDWARD CHESHIRE, Cuir bouilli armour, Why Leather: The material and cultural dimensions of leather, Leiden, 2014, 41-76. crushed roots are boiled and strained, and the liquid is used as a substitute for soap.

39. Polishing agent made of iron oxide.

40. Aralditâ data sheet, https://www.kremer-pigmente.com/ media/pdf/97970e.pdf [9/11/2021].

41. Japanese paper has long been used in object conservation for backing, facing and filling gaps, for example KAMINITZ, LEVINSON, 1989, 1-7. ARTAL-ISBRAND, 1-15. Examples of conservation treatments of leather using Japanese paper and adhesives can be found in DIGNARD, 2013a, Literature Survey of Repair Adhesives, Backing Materials and Application Methods for Skin and Leather Treatments, Ottawa: Canadian Conservation Institute; DIGNARD, 2013b, Adhesive Backing Treatments for Skin and Leather Objects: An Annotated Bibliography, Ottawa: Canadian Conservation Institute.

42. Beva 371 is an adhesive mixture based on ethylene vinyl acetate (EVA). DOWN, MACDONALD, TETREAULT, WILLIAMS, 1996, 19-44.

43. VAN GOGH, Golden Acrylic colour, Royal Talens, www. royaltalens.com.

LAURA DAVIES, Cuir bouilli, Conservation of Leather and Related Materials, Routledge, 2006, 94-101

CAROLE DIGNARD, Literature Survey of Repair Adhesives, Backing Materials and Application Methods for Skin and Leather Treatments, 2013a, http://www.icom-cc.org/54/document/adhesive-repairsfor-leather-literature-survey-table-may-2013/?id=1212\#.UbgmktiOPWM [9/11/2021].

CAROLE DIGNARD, Adhesive Backing Treatments for Skin and Leather Objects: An Annotated Bibliography, 2013b, http://www. icom-cc.org/54/document/adhesive-repairs-for-leather-annotated-bibliography-may-2013/?id=1211\#.Ubgld9iOPWM [9/11/2021]. LUBA DOVGAN NURSE, VALENTINA LJUBIĆ TOBISCH, Investigation and conservation treatment of two leather-covered cases, associated with the ewer and basin, attributed to the Nuremberg goldsmith Peter Kuster, ca. 1550, 2nd Heritage Science Austria Meeting 2021, Vienna, 17 September 2021, https://lubanurse. files.wordpress.com/2021/11/leather-cases-peter-kuster_dovgannurse_ljubic-tobisch_2021-2.pdf [9/11/2021].

JANE DOWN, MAUREEN MACDONALD, JEAN TETREAULT, SCOTT WILLIAMS, Adhesive Testing at the Canadian Conservation Institute: An Evaluation of Selected Poly (Vinyl Acetate) and Acrylic Adhesives, Studies in Conservation 41, 1 (1996), 19-44 MAX FRANKENBURGER (ed.), Beiträge zur Geschichte Wenzel Jamnitzers und seiner Familie. Vol. 30, Beiträge zur Deutschen Kunstgeschichte, Strasbourg, 1901, 96

CARL HERMANCK, Die Kunst der europäischen Gold- und Silberschmiede von 1450 bis 1830, Munich, 1978. 
ALFONS HUBER, WIEBKE LÜDERS, ALBRECHT CZERNIN, Ein Flötenfutteral aus dem 16. Jahrhundert im Kunsthistorischen Museum, Holzobjekte und Holzoberflächen, 29 (2010), 187-194 RAINER KAHSNITZ, WILLIAM D. WIXOM, Gothic and Renaissance Art in Nuremberg, 1300-1550, Munich / New York, 1986. MARIAN KAMINITZ, JUDITH LEVINSON, The conservation of ethnographic skin objects at the American Museum of Natural History, Leather Conservation News, 1 (1989) 1-7

PETRA KAYSER, The intellectual and the artisan: Wenzel Jamnitzer and Bernard Palissy uncover the Secrets of Nature, Australian and New Zealand Journal of Art, 7 (2006), 45-61

JOHANN NEUDÖRFFER, ANDREAS GULDEN, GEORG WOLFGANG KARL LOCHER, Des Johann Neudörfer Schreib- und Rechenmeisters zu Nürnberg Nachrichten von Künstlern und Werkleuten daseIbst aus dem Jahre 1547, nebst der Fortsetzung des Andreas Gulden, nach den Handschriften und mit Anmerkungen hrsg. von Dr. G.W.K. Lochner, Vienna, 1875.

MARION KITE, ROY THOMSON, Conservation of leather and related materials, Oxford, 2006.

FRIEDRICH KOBLER, Futteral, Reallexikon zur Deutschen Kunstgeschichte, 2016, https://www.rdklabor.de/wiki/Futteral [20 May 2021]. WOLFRAM KOEPPE, Ewer and Basin with Live Casts, Making Marvels: Science and Splendor at the Courts of Europe, New York, 2020, 64

ERNST KRIS, Der Stil „rustique“. Die Verwendung des Naturabgusses bei Wenzel Jamnitzer und Bernard Palissy, Erstarrte Lebendigkeit. Ernst Kris - Zwei Untersuchungen, Vorgestellt von Bettina Uppenkamp, Zürich, 2012/1926, 27-137

VEERLE MEUL, Safeguarding the significance of ensembles: value assessments in Risk Management for Cultural Heritage, ICOMCC 15th Triennial Meeting 2008, New Delhi, II (2008), 1048-1053. SIGRID MÜLLER, unpublished diploma thesis, Lederfutterale des 15. bis 18. Jahrhunderts, Stuttgart, 1998.

REX LINGWOOD, Boxes and bowls?, Cuir bouilli: experimentelle Gestaltung in Leder, Offenbach am Main, 1996.

VALENTINA LJUBIĆ TOBISCH, Peter Kuster's Ewer and Basin from the Treasury of Dubrovnik Cathedral: Scientific and Technological Analysis, Portal, 11 (2020), 91-108
VALENTINA LJUBIĆ TOBISCH, ROBERT LINKE, Fröschebein und Krebs und Fisch - Untersuchung und Restaurierung eines Waschtischsets, hergestellt von Peter Kuster in Nürnberg um 1550, Beiträge zur 26. Tagung des Österreichischen Restauratorenverbandes, 17 (2020), 119-133

MILAN PELC, Renesansa u Hrvatskoj, Zagreb, 2004.

CHRISTOPH ERNST PREDIGER, Für die Buchbinder und Futteralmacher, Reprint of the book of 1764, 2006.

RALF SCHÜRER, Vom alten Ruhm der Goldschmiedearbeit, Nürnberger Silber in Europa, Quasi centrum Europae: Europa kauft in Nürnberg 1400 - 1800, Nürnberg, 2002, 175-197

WILFRIED SEIPEL, Die Entdeckung der Natur, Naturalien in den Kunstkammern des 16. und 17. Jahrhunderts, Vienna, 2006.

JEFFREY CHIPPS SMITH, Nuremberg, a Renaissance City 1500 1618, Texas, 1983.

PAMELA H. SMITH, In a Sixteenth-Century Goldsmith's Workshop, The Mindful Hand: Inquiry and Invention from the Late Renaissance to Early Industrialization, Amsterdam: Koninklijke Nederlandse Akademie van Wetenschappen, 2007, 32-57

PAMELA H. SMITH, TONNY BEENTJES, Nature and Art, Making and Knowing: Reconstructing Sixteenth-Century Life-Casting Techniques, Renaissance Quarterly, 63 (2010), 128-179

VIRGINIA SPENLÉ, Wenzel Jamnitzer's Mortar: Life Casting and Court Experimentalism in the 16th Century, Collecting nature, Newcastle upon Tyne, 2014, 37-56

HÉLĖNE VEROUGSTRAETE, Frames and Supports in 15th- and 16th-Century Southern Netherlandish Painting, Brussels, 2015, http://org.kikirpa.be/frames/files/assets/basic-html/toc.html [10/4/2021].

ANNA WEINBERGER, unpublished diploma thesis, Lederfutterale. Verkannte Beschützer. Konservierung, Restaurierung, Aufbewahrung und Handhabung von Lederfutteralen am Beispiel des Futterals der Pretiosen-Monstranz (1697) aus dem Dommuseum zu Salzburg, Vienna, 2009.

\section{Sažetak}

Luba Dovgan Nurse, Valentina Ljubić Tobisch

\section{DVIJE FUTROLE PRESVUČENE KOŽOM KOJE SE PRIPISUJU NIRNBERŠKOM ZLATARU PETERU KUSTERU 1550. GODINE}

Carski grad Nürnberg u 16. stoljeću postaje jedno od najvažnijih središta zlatarskog zanata i proizvodnje luksuzne robe Svetog Rimskog Carstva. Usvajanje luteranizma (1525. godine) imalo je velik utjecaj na razvoj umjetnosti te je donijelo promjene $u$ tradicionalnim oblicima crkvene zlatarske umjetnosti, poput liturgijskih predmeta, relikvijara i križeva. Crkva je, naime, prestala biti glavni pokrovitelj umjetnosti te su se pojavili novi pokrovitelji, poput urbane aristokracije, koja je naručivala svjetovne predmete. Umjetnici su razvijali nove sekularne stilove, a izlaganje rukotvorina u stambenim prostorima postajalo je sve važnije, odražavajući renesansnu ideju prikupljanja i prikazivanja jedinstvenih, rijetkih i nesvakidašnjih stvari koje su stvorili priroda i čovjek. Želja za prikupljanjem i izlaganjem artefakata dovela je do razvoja novih vrsta namještaja poput ormara i umjetnički izrađenih ormarića. Futrole rađene po mjeri mogle su biti zanimljive za izlaganje, a pritom ostati funkcionalne te su, uz pri- 
jašnje vrste namještaja za pohranu poput škrinja i kutija, postale vrlo važan element brige o unikatnim predmetima. Futrole su rađene po mjeri i naručene $u$ isto vrijeme kada i predmeti. Povijesni kompleti srebrnog posuđa i originalnih futrola mogu se shvatiti kao ansambl, koji se procjenjuje, tumači i čuva kao cjelina.

U Dubrovniku su sačuvane dvije zaštitne futrole kao dio veličanstvenog kompleta za umivanje koji se sastoji od vrča i umivaonika poznatog po obilju naturalističkih odljeva životinja i biljaka. Komplet vrča i umivaonika iz Moćnika katedrale Uznesenja Djevice Marije u Dubrovniku, datiran oko 1500. godine i pripisan nirnberškom zlataru Peteru Kusteru, godine je 2019. podvrgnut tehnološkom i znanstvenom istraživanju te konzervatorsko-restauratorskim radovima. Projekt je pružio priliku da se ispitaju jedinstveno očuvane originalne kožne futrole i da se provedu minimalni konzervatorsko-restauratorski radovi kako bi se poboljšalo njihovo stanje i vratio originalan izgled.

Najprikladniji je izraz koji opisuje takav tip navlake rađene po mjeri, Futteral na njemačkom, futrola na hrvatskom i case na engleskom. Francuski izraz etui često se koristi kao sinonim za Futteral, no etui je ispravnije koristiti za male, ravne futrole koje ne prate oblik predmeta, te futrole s otvorom za umetanje predmeta. Futrola se uvijek izrađuje po mjeri za unikatni predmet. Silueta predmeta određuje oblik futrole, a budući da je izrađena po narudžbi, rijetko se mogla koristiti za neki drugi predmet. Postojala su tri glavna načina izrade futrola: od drva, od ukalupljene kože cuir bouilli, i od kompozitnih materijala s drvom ili papirom kao temeljem, te podstavljenih i ukrašenih kožom, tkaninom, pergamentom, ribljom kožom ili papirom, često reljefno obrađene i pozlaćene površine, te metalnim kopčama. Na dekoraciju futrole utjecao je tadašnji stil, a futrola je odražavala društveni položaj vlasnika i ukazivala na vrijednost predmeta koji se nalazi u njoj. Vješto obrađene šarke i kopče te ukrasi aplicirani na kožu, poput rezbarenja, punciranja, graviranja i pozlate, naglašavali su luksuzan izgled. Futrole su bile relativno lagane i jednostavne za nošenje i transport.

U izradi futrola su sudjelovale knjigoveže i izrađivači futrola. Grad Nürnberg je, naime, 1631. regulirao proizvodnju futrola, te je njihova izrada bila dopuštena dvama zanatima: mogle su ih izrađivati knjigoveže, uz uvezivanje knjiga, a uspostavljen je i zaseban zanat izrade futrola, pri čemu je izrađivačima futrola bilo zabranjeno raditi išta drugo. Nije bilo cehovskih propisa o primjeni majstorske punce na futrole, kao za predmete koje su izrađivali zlatari, što otežava identifikaciju radionice. Povezivanje futrola s regionalnim stilovima ili pojedinim radionicama moguće je kroz grbove i natpise ili međusobnom usporedbom.

Problemi restauriranja futrola dijele se $u$ tri skupine: 1) strukturalne deformacije i savijanje drva; 2) infestacija insektima i kukcima koji se hrane drvom, ljepilom, kožom na vanjskom dijelu i podstavom; 3) habanje vanjskih i unutarnjih površina te oštećenje pozlate uslijed mehaničkih oštećenja i rukovanja. Iako su na futrolama iz Dubrovnika prisutne sve tri vrste oštećenja, one su i dalje $u$ relativno dobrom stanju. Futrole su prije konzervatorsko-restauratorskih radova pregledane rendgenom, svjetlosnom mikroskopijom i SEM/EDX analizom, kako bi se dobile informacije o materijalima i tehnikama izrade, njihovoj povijesti i prijašnjim restauratorskim radovima.

Proučavanje ovih futrola i srebrnog posuđa kao cjeline bilo je korisno za procjenu povijesnog značenja kompleta za umivanje, te za razumijevanje materijalnog stanja $u$ cjelini. Konzervatorsko-restauratorski radovi najprije su usmjereni na strukturalnu stabilizaciju drva, kože i svilene obloge te smanjenje voštanog premaza s ciljem otkrivanja izvornih punciranih i graviranih ukrasa. U bliskoj budućnosti futrole će biti izložene uz srebrno remekdjelo pladnja i vrča Petera Kustera. Usporedba između zlatarskih djela Petera Kustera i Wenzela Jamnitzera može se proširiti na kožne futrole povezane sa srebrnim posuđem. Sličnost između futrole za Merkelscher Aufsatz (Merkel's Table Piece) i futrole za Kusterov vrč zaslužuje daljnje istraživanje.

KLJUČNE RIJEČI: renesansne kožne futrole, Nürnberg, Peter Kuster, Moćnik dubrovačke katedrale, utisnuta koža, zlatar, konzervatorsko-restauratorski zahvat 